\title{
Theology, Martyrdom and Female Agency in Reformation Prague
}

\author{
Thomas A. Fudge
}

check for updates

Citation: Fudge, Thomas A. 2021. Theology, Martyrdom and Female Agency in Reformation Prague. Religions 12: 748. https://doi.org/ $10.3390 /$ rel12090748

Academic Editor: Denise Starkey

Received: 20 July 2021

Accepted: 3 September 2021

Published: 10 September 2021

Publisher's Note: MDPI stays neutral with regard to jurisdictional claims in published maps and institutional affiliations.

Copyright: (C) 2021 by the author. Licensee MDPI, Basel, Switzerland. This article is an open access article distributed under the terms and conditions of the Creative Commons Attribution (CC BY) license (https:/ / creativecommons.org/licenses/by/ $4.0 /)$.
School of Humanities, Arts and Social Sciences, University of New England, Armidale 2351, Australia; tfudge@une.edu.au

\begin{abstract}
The Hussite tradition historically has been excluded by the mainstream of Reformation historiography. Czech-language scholarship treating Hussite history have made few significant advances in the study of women and there has been limited attention given to the role women played in the Hussite tradition. The gap in Anglophone historiography is even more apparent. This essay considers Klára, a sixteenth-century Prague housekeeper, Marta, a learned figure contemporary with Klára who withstood civil and ecclesiastical officials, and Anna Marie Trejtlarová, an early seventeen-century educated laywoman. Their names are almost completely unknown outside Czech historiography. An examination of their lives and faith by means of the surviving primary sources and relevant historiography provides a window through which to observe the nature of religious reform in the Prague context in the world of Reformations. What is striking is the role of theology and the nature of female agency in the examination of these women. The essay endeavours to use these case studies to present a preliminary answer to the question: What do women tell us about Reformation? This study reveals the world of religious reform more fully by situating women and female agency in an active capacity.
\end{abstract}

Keywords: Anna Marie Trejtlarová; female agency; heresy; Hussites; Klára; Marta; martyrdom; Mikuláš Vřetenář; Reformation; sodomy; theology; women

\section{Introduction}

The history of religious practice in the Latin West has often excluded women from the main narratives and they have been overlooked in traditional scholarship. We know a great deal about those in official religious orders and there has been a fair amount of conjecture about women in heretical movements though much of this has been unable to sustain the weight of close interrogation. ${ }^{1}$ It is a frail argument to maintain that heresy appealed to medieval women more than men. ${ }^{2}$ Within Christianity, women have been equally praised and excoriated. In the past generation they have increasingly become the subject of serious consideration. This is especially true for the sixteenth-century Reformations but less so for the Hussite movement where scholarship has not progressed. ${ }^{3}$ We know that women did respond to the reform impulses that coursed through the Czech lands in the last quarter of the fourteenth century, arose to prominence in the fifteenth century, and continued into the early modern period. It is also evident that women in the world of Reformation did not simply passively react to the various reform messages that arose. Finding sources, especially in the Hussite context, has been especially onerous. The stultifying effect of the Counter Reformation almost completely extinguished the Hussite tradition and in the course of re-catholicizing Bohemia many sources were lost. That said, it is also pertinent that Hussite sources tended to marginalize the witness and role of women. Naturally, fewer women than men left records behind and chroniclers tended to overlook women save when they became public figures in revolt or martyrdom or otherwise gained compelling notoriety. Much that was said about women in the Middle Ages and the general period of the Reformations may rightly be questioned or dismissed as outright nonsense. What 
is difficult to dislodge from an evidentiary point of view is the overwhelming sense that women were regarded inferior to men in almost every respect.

The most recent approaches to the study of Reformation and religious beliefs of ordinary people, two scholarly generations after the pioneering work of Roland H. Bainton, have been informed partly by the desire to put theology back into Reformation studies, not only in response to those who have sought to reduce the field to political or social history but also to address the thesis that reform (on the part of any of the churches) achieved, at most, confessionalization as a mode of group identity. ${ }^{4}$ Such identity has been assumed to have been largely imposed from above. In some cases, this has been coupled with the view that most ordinary Christians remained anticlerical and retained a merely superficial or lingering folkloric or paganized understanding of their religion in the run-up to the mass dechristianization that was presumed to start in the eighteenth century. Among the leading revisionists of this thesis is the work of Brad Gregory who demonstrates that ordinary Christians of whatever persuasion knew much more about the theology of the faiths for which they suffered and sometimes died than has hitherto been thought (Gregory 1999). Hussite history may yield some of the same kinds of sources and connections on which Bainton and Gregory have relied and these largely unknown narratives can shed light on questions about women in general and more specifically on Hussite history and the nature of Reformation.

Women in the Reformation period had some opportunity to participate in a turbulent era in which there were profound religious changes and extraordinary intellectual developments. The Hussite moment in Bohemia transformed Czech society while the broad thrust of the European Reformations presented a serious challenge to society and helped to transform western civilization. The role of women in these upheavals was complex and contested. This being so, it is impossible to assess the nature of Reformation without taking into account the ways in which women responded to the multiple impulses that affected religion and society. This includes evaluating the ways in which women participated in religious reform but also the manner in which those same developments affected women. ${ }^{5}$ By looking at three specific females within the Hussite movement in the post-medieval world, it is possible to expand our understanding of the ways in which women reflected and informed the impulses of Reformations that swept the religious worlds of early modern Europe bearing in mind there is no fundamental cultural change between the medieval period and the age of Reformation (Corbellini and Steckel 2019). These historiographical politics must be discarded. By rescuing these women from the historical fate of faceless anonymity and neglect, we are better able to contribute to the question of what we can learn from women about religious Reformations. The idea of female agency in the clash of religious ideologies is one that remains an outstanding question in Hussite history. There cannot be a single explanation or unified narrative for the simple reason that the female experience was shaped by a myriad of factors. ${ }^{6}$

\section{Anna Marie Trejtlarová}

Women in the Hussite tradition have continued to emerge from the dimness of the past every so often and their lives and activities shed light on important though overlooked and forgotten aspects of the religious history of Europe. By the early seventeenth-century, for example, Anna Trejtlarová, Anna Marie's mother, left her homeland together with her relative Kristina for the sake of religious devotion. ${ }^{7}$ She preferred exile and her faith rather than remaining in Bohemia where she would have to deny her convictions. She was a wealthy widowed noblewoman living in Prague. Her daughter, Anna Marie Trejtlarová of Krošvice, was sufficiently literate to transcribe sermons of some of the Unity of Brethren preachers, a second-generation variant of the Hussite tradition (Hradec n.d.). These included the homilies of Matěj Cyra (or Cyrus), Jan Cyril, and Matěj of Boleslav, delivered between 1610 and 1618. ${ }^{8}$ The Czech historian of religion Ota Halama believes there are two different hands present in the extant manuscript and there is no reason to think that Anna did not assist her daughter in this project (Halama 2018, p. 192, n.41). The postil, 
or collection of sermons, bears an inscription by Anna Marie wherein she reveals: "I was eighteen years old at that time, when I heard the word of God from the honorable men and servants of God in the temple of the Lord of Bethlehem [Chapel]." ${ }^{\prime 9}$ Anna Marie and her mother attended Brethren services in the Bethlehem Chapel after 1609 and Anna appears in the Tuchoměrice register of Unity of Brethren members from 1607 (Halama 2018, p. 185). Anna Marie's literary estate contains a number of Brethren writings. One of these is an anthology of twelve texts relating to the Brethren at Tuchomerrice dating to 1584 (Halle 1584). Her mother inscribed the last page with the words: "My soul waits silently for the Lord. He is my hope and my salvation." Anna Marie added that one should keep the good treasure by means of the Holy Spirit. Another important text includes her records of the sermons delivered at the Bethlehem Chapel. To these transcriptions Anna Marie attached one of her own prayers. Some scholars argue this prayer provides us with the most conclusive proof for the education of women within the Unity of Brethren (Císařová Kolářová 1942, pp. 229, 308-10). This may be so but it tells us little about women. Happily, we know a fair amount about the lives and fates of Anna Trejtlarová and her daughter Anna Marie. Anna Marie was the eldest daughter of Václav Trejtlar, a wealthy burgher and merchant (1563-1606), and his wife Anna who adhered to the religious faith of the Brethren and had been active at Klatovy, a town in southwest Bohemia and a stronghold of Hussite religion during the revolutionary period 200 years earlier. Her father was a cloth trader while her mother, Anna Mrázová of Milešovka, had been a well-to-do burgheress in Litoměřice. The Trejtlar family has ancestral roots in Świdnica in Silesia and Crostwitz in Lusatia.

In June 1562, Anna Marie's grandfather Petr Trejtlar married Zuzana Karbanová of Tryskov who belonged to a family living in the New Town of Prague. Petr is likely to have begun the cloth business his son Václav inherited (Halama 2018, pp. 182-83). Václav and Anna had two daughters, Anna Marie, born in 1593/4 and Ludmila Zuzana a year or two later. Václav died in his early forties and sometime after the Protestant defeat at the battle of White Mountain in 1620 Anna Trejtlarová (Anna Marie's mother) went into exile, choosing to live abroad rather than converting to the politically-dominate Catholicism. The tale of her life is the story of an emigrant to Saxony after White Mountain. A recent study by the Czech historian Barbora Jiřincová has outlined what is possibly a typical situation characteristic of Czech women during the Reformation era (Jiřincová 2015, pp. 2-11). Clearly, Anna's daughter Anna Marie had taken advantage of the education opportunities offered by the Hussite tradition, in this case the Unity of Brethren. Being forced to emigrate because of her non-Catholic faith and allegiance to a minority religious practice meant that Anna lost all of her substantial property. For example, there was a residence in Tuchoměřice (a village northwest of Prague) while in the New Town of Prague she owned a house near the Church of St. Henry at the corner opposite the Water Pool [Louže] and the bell tower [proti zvonici], a second house in what is today Jungmannova Street, and a third in Na Př́kopě Street. In the Old Town, she owned a house called "At the Black Bears" in Železná Street, along with another house in Melantrichova Street. At the north Bohemian town of Litoměřice, Anna had properties including a house near the Dlouhá brána (Long Gate), a house in Voldaňy that included a courtyard, the little village Za Brankou, a village in Oujezd, and elsewhere there were vineyards, one under Radobýl, another on Chlonek, a shed with a barn in Hroby, along with other cottages, barns, and gardens. The value of her assets totalled more than 12,000 kopa. ${ }^{10}$ Her daughter, Anna Marie, was heir to this wealth but she died prematurely. After leaving Bohemia, the widow Anna wandered throughout various places in Saxony, taking refuge in Dresden in 1640. Later, in the 1660s, her younger daughter, Ludmila Zuzana Orsinová, unsuccessfully tried to regain the property in Prague near the Church of St. Henry that had been confiscated. It is difficult to know how typical this scenario was for women in the Czech lands in the Counter Reformation period. While there is no evidence that Anna Marie ever went into exile, and we have no plausible explanation for why she chose to remain in Prague, the fate of Anna Trejtlarová and her daughter Anna Marie is not anomalous and must surely reflect the exigencies endured by women during periods of religious upheaval, outbreaks of heresy, and in her case, the 
forced recatholicizing of the Czech Lands. ${ }^{11}$ Anna Marie never married but instead lived a life of religious piety and spirituality having committed herself to her mother and her faith.

The prayer Anna Marie composed in the Czech language and attached to the Bethlehem Chapel Postil is worth reading for the light it sheds on the faithful devotion of a Czech woman caught up in the drama of religious Reformation and committed to the spiritual community of the Unity of Brethren. The full text of the prayer follows:

Almighty, eternal and alone for all ages blessed, my Lord God, who is the God of all mercy and compassion. Father of all inexpressible love and goodness, inexhaustible fountain of all good gifts, in you alone eternal salvation is deposited. Outside of you there is nothing but damnation. I thank you cordially, highly and in all ways humbly and submissively for all your benefactions, private and public, made and proven to both sides of my life. Above all and especially for your immense, unmeasurable, and most wonderful grace and love, which has become for me that you have [as I strongly believe] right after the creation of the world. This is not according to my merit or faith or good deeds, which I would perhaps have had or done, but according to your deep mercy and your good pleasing will in Jesus Christ, my Lord, you saw fit to love me so much. From that enormous love and grace you turned to me and chose me, apart from worth and merit on my part. Even when I was an enemy, when in wines and sins I was mortified, when in no way could I merit it from you, my most holy Lord God. In truth I did not know how to think about how such a great, enormous, dear and of inestimable worth [that is] the mercy of God should have happened. When I try to remember with special joy in my heart, I almost shake in fear. Oh, Lord God, I am amazed by your mercy, considering that you had no need of me. Moreover, that you already have an uncountable number of servants-angels, saints, those pure spirits, who always stand ready to carry out your will in all things. To say nothing of having among your devotees other true, pious, and eager admirers. I say, not even me being so timid, and such an unworthy little servant, I am among all your admirers and female servants the smallest one, the last one, the least desirable one. I am nothing but dust and ashes. I am much less than nothing before your holy face; yet you did not choose to reject me, but rather counted me with, and added me to, the number and rank of all the believing and chosen ones. When I stood on the road to perdition, and in sin and unrighteousness hurried toward my eternal damnation-you intercepted me, and redirected me. When I was not worthy of it, you turned your gaze on me, nevertheless with wide open eyes of mercy, you chose to look and see me and more than that, to reach to me with your hand, and to pull me toward yourself; to tear me out of the devil's kingdom, and transfer me to the kingdom of your dear Son; above which is your grace.

Oh, Lord God, surely nothing dearer, nothing rarer or greater, could have happened, than that even now through faith, I have been made a daughter of God, and in hope, also an heiress of the eternal and beatific life. This thy mercy, oh, Lord God, soothes me in all sadness and in various waverings of the spirit gives me joy not only in this life, but will give me joy (as I believe) also in death, thanks to the fact that nothing can tear me away from your most merciful hands, and deprive me of your fatherly love according to your merciful promises, which also-as I believe-refer to me. As you kept saying, how could a mother forget about her child, not to feel pity for the fruit of her life, and even if she should then forget, I shall not forget you, that is my people, because I sculpted you with my own hands. Hence, nobody will tear you out of my hands. And this gives me joy, my most merciful Lord God, and I believe that nothing will tear me away from your merciful hands, not even your prime enemy-the devil, nor all my sins (despite being horrible, numerous, and great). Neither life, nor death, neither attractive nor repulsive things, will be able to deprive me of your love because 
it depends, not on me, but on you. Trusting your divine mercy that you who choose - without any consideration of my worth or merit - to begin in me the good work, will deign also-without any of my worthiness-to complete the good work in me until the coming of the Lord Jesus Christ. Because with you, my Lord God, I stand, without you I fall; whether alive or dead, by myself I am falling. Yet I persist, whether I stand or fall, whether alive or dead. By myself I fall, by myself I cannot rise. Only when lifted by you can I stand on my feet. Without you I am faint. Only in you am I strong. Without you, I am dead, in you, I am alive. In sum, without you I cannot do anything, but in you and in your power I can overcome everything.

In the meantime I thank you, my dearest Lord God, out of the entirety of my heart, that you condescended, out of pure mercy, to create me according to your image and resemblance, to adorn and enrich me with justice, sanctity, innocence, true reason, direct will, and many other gifts. Above that, when I, a great and miserable sinner, did remain long in that condition, but-in my original parentsexceedingly seriously, and soon sank and fell. Oh, God, my Lord, I disobeyed your injunction and obeyed the enemy, the devil. By this I deprived myself of everything good, and ran into everything evil. Yet I can say that even then, my eternal Lord God, when you could do so justly, still you did not reject me forever from you and your kind face, and you did not forget your mercy. Though you could have condemned me, you deigned instead to save me eternally, and from that immense and paternal love-and more than fatherly — that you chose again to lift me up and accept me in your grace. You perfectly returned to me the right of eternal life in salvation, and everything good in your dearest Son, the Lord Jesus; whom you then-for me as well as other believers and elected ones-sent into this world, and handed him over for my redemption. Through him you liberated me from the power of the enemy-the devil, and also purified me from my sins, and made me valuable and dear for his own self. Oh, my Lord God, surely what more could you have done and given, than when you gave me your dearest and only Son, above whom you had nothing more dear or rare, and in him your own self? Moreover, that you called and drew me to him into that holy church and company of your faithful people; and then also in the eternal feast, you gifted me with the Holy Spirit, and through him sanctified, again gave me birth, internally and externally, in my soul and in my body corrected and renewed me. You also gifted me with a life of repentance, true faith, and a clean conscience. In addition, you made me a participant in all the treasures deposited in your Holy Church and furnished me here with faithful servants. You gave me awareness of the forgiveness of sins, and the attainment of salvation and all this you confirmed and sealed with your word and sacraments. You also supported and confirmed the hope in the future resurrection of my body from the earthly dust and the glorification with my dearest husband the Lord Jesus Christ.

I also thank you greatly, oh, my eternal Lord God, for these great benefactions, which refer to my temporal and earthly life. First of all, that you retain me in being in this miserable world and maintain in allowing me the time of grace. In this you support my life, feed me, clothe me; and you furnish me with various comforts both for the soul and body and whatever contrary and repulsive, you deign to impose on me, all of that-I believe-you choose always to do only for the sake of my eternal salvation. Thus, it is not out of your anger (which I do deserve) but out of fatherly love, thereby to train and teach me; and everything that you discerningly choose to do as a reasonable and prudent Father, knowing perfectly what and when I need it. Therefore, it is good for me to stay often in your little penitentiary and to learn to know your holy commandments. In addition to all that, you deign to treat me very kindly, and do not load anything on me above my ability, rather placing your gracious hand under me, and in this 
manner helping me so that until the end I would not fall and be destroyed. For all these spiritual and physical benefits, oh, my dearest Lord God, I thank you deeply, I praise and glorify your holy name, which is worthy of all honor and praise.

May I praise you, for them [benefactions], along with heaven and earth. May the holy angels in heaven and all your chosen ones on earth glorify you, because you made all things well; you benefitted me, when you had chosen me and created me, according to your image. You did marvellously, when you redeemed me through your dear Son, and called and introduced me to him in the Holy Church. You benefitted me when you sanctified me through the Holy Spirit. You benefit me in life, you will benefit me more at death, and you will benefit me most-as I believe-after death. Therefore. I beg you, oh my Lord God, allow me to cherish highly and dearly all of these your benefits. Never release them from my memory and from my heart but rather seek to demonstrate in my person my election and calling. Amen. ${ }^{12}$

A close reading of this prayer, attached appropriately to the sermons of the Prague Brethren, reveals a nuanced understanding of religious faith that approaches spiritual autobiography. It sheds light on religious belief and practice in Reformation Europe. The prayer of Anna Marie Trejtlarová is a short expression of thanks to God for leading her in a spiritual journey to embrace the correct faith. The prayer also reveals Anna Marie's conviction that the Unity of Brethren was the true Christian Church. She expresses gratitude to God for having enabled the rise and development of the Church, and that she had been permitted to learn from the Brothers. Theologically significant, Anna Marie refers to being in the image of God. It is possible to attribute too much to the prayer but it is impossible to avoid overlooking the theological depth present therein. This is especially apparent when Anna Marie refers to the doctrines of election and predestination mentioning this soteriological principle as being in force from the creation of the world. This is a Calvinist emphasis. By the seventeenth century, Calvinism had made significant inroads into Protestant Bohemia, especially amongst the Unity of the Brethren. A discrete Reformed church was not established but Calvin's ideas could be found with ease (Ǩíčan 1992, pp. 264-75; Benedict 2002, p. 268). Anna Marie identifies with this doctrine and gives thanks to God that she has been included among the elect. The prayer reflects additional theological acumen by acknowledging that the mercy of God is joined with faith and the elect are those who are recipients of that mercy and their standing in the kingdom of God does not depend on social status. This harkens back to the social egalitarianism promoted and practiced by Czech reformers from the last quarter of the fourteenth century with Jan Milíc of Kroměříž and onwards through the Táborite period. Here we also encounter evidence of the Reformation doctrine of justification by faith presented through the media of Calvinism and its Bohemian reception. Taking into account the doctrinal trajectory of the Unity which, in the first half of the sixteenth century, was greatly influenced by Martin Luther especially in his emphasis on faith, this aspect of the prayer is quite exceptional because it suggests that Anna Marie possessed a good understanding of what the priests taught along with a solid knowledge of one of the key theological tenets of the sixteenth-century Reformations. Her faith remained firm "in the time of grace:"

I know that my Savior and Redeemer from eternal death, is alive and reigns with the Father; and is upholding me by his power. I know that at the Last Judgment I will be resurrected from earthly dust. I will put on a glorified body dressed in a new skin. I shall see God in my new body. This hope is deposited and rooted in my heart. I have believed in him, he is powerful enough to resurrect me. In him I shall not experience any shame, but will attain glorification. I commend my soul to him. I know that he will ultimately accept it. Therefore, I shall die in safety. ${ }^{13}$

Anna Marie's prayer is sophisticated and characterized as an outstanding example of religious writing among the members of the Unity of Brethren at the beginning of the 
seventeenth century (Hanušová 2013, pp. 180-81). It is significant that the Trejtlar family maintained close association with prominent Brethren such as the lawyer Jan Theodor Sixt of Ottersdorf (1569-1654) and the publisher Daniel Adam of Veleslavín (1546-1599) (Halama 2018, p. 184). If the ethos of Anna Marie's prayer is applied to her mother, it becomes the testament of a woman who chose the "life of an outlaw rather than betraying her faith." (Císařová Kolářová 1942, p. 310).

Anna Marie Trejtlarová died in Prague at "thirty-two years of age, thirty-two Sundays and three days, on the Friday after the remembrance of the Magi, that is, on 9 January 1626 at two o'clock having happily completed her life in the Lord and now awaiting the glorious resurrection of the dead." We have two funeral orations delivered at the church of St. Benedict in the Old Town of Prague by Pavel Černovický, a Unity of Brethren minister from Německý Brod. These were printed in January 1626. The first represents the deceased speaking to her family and loved ones while the second offers comfort to the mourners. Anna Marie says she served God as long as she lived and divine grace received her into God's joy out of the misery of the present evil world. She encourages her sister Ludmila Zuzana to remain firm in the faith, taking her place, and avoiding all evil. She acknowledges that Christ protected her from the "horrors of hell" and had been a "comforter and a savior in the sadness of these times" that were in the hands of God. Pavel Černovický noted that God "came and took her into eternal comfort." The Son of God forgave all sins so that all "might have peace at the hour of death." Anna Marie knew God and "walked through faith into eternal life." Through the wounds and death of Christ, she was comforted, and in certain hope was taken from misery. "Death was overwhelmed and she died in the Lord and is now honoured with the crown" of eternal life. To those who remained, Černovický conveyed the hope that when they had finished their fight they would see Anna Marie again. Therefore, "let us die the death of the righteous and find a safe dwelling in heaven. Amen". ${ }^{14}$

It was impossible to conduct the funeral in Bethlehem Chapel because this was now in the hands of Jesuits and most non-Catholic priests had been expelled from Prague in 1624. The cause of death is unknown though the plague had been in Prague in the months preceding her death. The lives of the Trejtlarová women, mother and daughter, deserve to be better known as participants and agents of Reformation.

\section{Hussite Women}

Anna Marie Trejtlarová was neither exceptional nor unprecedented. Too often we are left with shadows of women in actu and with a preponderance of speculation about women in potencia. The res gestae of women in the Hussite Revolution appears lost; their achievements often unnoticed. Anna Marie's life is only partially visible. She and her mother "remained in the shadows during the stormy times, public activities were left to men." (Halama 2018, p. 193). What is clear in Hussite Bohemia is that while the movement was well supplied with pious women, the reformers did not deviate significantly from standard medieval views of women (Kaminsky 1967, pp. 255-56). The Czech writer Tomáš Štítny (†1401), wrote books in order to educate his daughters and once posed the rhetorical query: "And have not women been prophets through whom God has worked wonderfully and done great things: Judith, Esther, the widow Anna, the Sibyls? Hence, though one should not believe any spirit, still not all simple folk, uneducated, or women should be excluded when they speak so, but it is proper to put it to the test to see if it be from God."15 Theoretically, this was fair comment and while Bohemian reformers like Jan Hus and Petr Chelčický held some non-traditional views about women, once again these were largely theoretical pronouncements that failed to gain serious or lasting traction. Nevertheless, there is a general assumption that Hussites did little to avoid the misogynistic Middle Ages (Šmahel 1993, vol. 2, pp. 38-39). Some Hussite thinkers and reformers were aware that the teaching of female subordination and their exclusion from positions of religious leadership and spiritual authority was rooted more in custom than in divine command and that ecclesiastical tradition might therefore be challenged. Few 
of the sixteenth-century reformers acceded to the idea that spiritual equality might take precedence over cultural concepts of obedience. One searches in vain for even a single major sixteenth-century reformer to declare that women might be theologians, preachers, or church leaders (Karant-Nunn and Wiesner-Hanks 2003; Douglass 1985; Thompson 1992; Wiesner-Hanks 2019; Stjerna 2009; Snyder and Hecht 1996).

Did religious Reformations give any consideration to women? Theoretically, the European Reformations possessed a sufficient arsenal to effect massive shifts for women but did not take that step and instead accepted traditional, scripture-based ideas of female subjection. ${ }^{16}$ Claims about the emancipation of women in radical religious movements like Anabaptism often fail to appreciate that this freedom did not include preaching, sacramental ministry, or formal leadership (Schäufele 1966, p. 298). This is a hollow echo from when women were priests and exercised a modicum of religious authority and leadership (Torjesen 1993; Madigan and Osiek 2005). Some of the Hussites not only tolerated but encouraged women to leave their husbands if the latter refused to accommodate the new reforms. Critics reported that "many young girls and women" took this advice literally and left everything behind, including husbands and conventional domestic roles, and entered a life of uncertainty (Příbram 2000, p. 40). Such actions were serious challenges to social and ecclesiastical authority and attracted condemnation. ${ }^{17}$

Within the Hussite movement we find evidence wherein opportunities for women were much increased but also restricted. From time to time, in the annals of the Hussite phenomena, we find women surging to the forefront in communities of violence and in the context of religiously-motivated riots. In the sixteenth-century we find examples of women insisting upon agency and autonomy because they regarded themselves as Christians moved upon by God and this standard was ever so much more important than traditional categories of femininity and womanhood. ${ }^{18}$ This was not new. A century earlier, Hussite women had taken a similar stand. Naturally, this caused friction and consternation amongst religious and civic authorities. This fear was exacerbated in situations when it became clear that women were theologically astute and capable of defending doctrinal propositions and holding their own intellectually as zealous polemicists or theological advocates. Hussite leaders appeared to tolerate such female action when the initiative deflected censorship from men, aided and abetted male agendas, or were construed as part of a larger program that served the interests of reform more generally. In the absence of more expansive data it is not possible to argue that the effects of the Hussite reform movement were more restrictive or liberating. That is a larger consideration for a less focused venue. Here, we can begin to consider the direct effects of Hussite ideology on women and perhaps the role women played on the influence of that ideology in practice.

Returning to the questionable and largely discredited notion of heretical movements attracting a preponderance of female adherents, it is useful to ask how women were represented within the Hussite movement. Is the female the hereticus pessimus [worst heretic] of the late medieval Hussite Revolution? One of the foremost thinkers in the early years of the uprising, Jakoubek of Střibro, asserted that the dissemination of the worst kinds of delusions throughout the Czech kingdom was the fault of large crowds of women. ${ }^{19}$ This statement has all the hallmarks of a trope. It can be argued that the Hussite movement appealed to women at every level of social standing, from noblewomen to housewives and prostitutes, possibly because the official Latin church mainly restricted female religious activity to the cloister. Fifteenth-century reformers generally welcomed the support of their cause by women but most of them harboured suspicion of females. Matěj of Janov is perhaps the single figure in the late medieval reform movement in Bohemia who appears positive about women and seems relatively unencumbered by medieval misogyny. He asserted: "For all that links one to God, to know faith, hope, charity, prayer, penitence, abstinence, chastity, humility, works of mercy and the exercise of virtue under all its particular forms, women who are in Jesus Christ are well ahead of men ... the women of our time who are in Christ, surpass men in virtue (Kybal et al. 1908-1993, lib. 1, tr. 2, reg. 4, c. 14 and c.15, in vol. 1, pp. 154, 155)." It is doubtful that Jakoubek agreed. 
Gender is clearly important in understanding the social and cultural dissemination and reception of Hussite ideas especially given that a stimulus for early reform was the pastoral work of Jan Milíč of Kroměřiž (+1374) among prostitutes in Prague. Milič́s practice of frequent communion was critical for support by these women, as were the views of radical Hussites for both males and females expressed most vividly, even if only temporarily, at Tábor. From an official religion point of view, the Hussite woman was the "magna mulier fornicaria" [great fornicating woman] (Kybal et al. 1908-1993, lib. 2. c. 1, in vol. 1, p. 179). Vernacular songs, like one titled "Bekyně" or "The Beguine," tended to make the point that no one should take women seriously. This pro-Catholic satire poked fun at women who dared assert their knowledge of scripture exceeded that of university masters and such compositions represent a sustained critique of Bible-reading female heretics.

"The Beguine"

Hear again, dear brothers,

The end of this song

Is coming to the clergy:

Announced to you by the sisters

They swore to the man

Each of them reached the devil,

They learned the alphabet,

They like to go out and chat.

They hypocritically read books,

Their tongue is lubricated [i.e. they are running off at the mouth]

They correct both old and young

But do not improve themselves.

They want to argue with everybody,

And let them know whatever they think

They did not learn Latin

Those talkative Beguines.

Masters, priests and disciples

Cannot resist them

Because they talk so much

But they act too little.

They have humble veils

But you should especially know

They appear to be very humble

But their hearts are immersed in sinful deeds.

They tie themselves in a roškop [a type of harness]

Like a German horse halter

They feel thus more spiritual;

Yes in many coverings [but many are hypocrites].

They do not go preaching

Some do not get tempting

Saying: we know better

Because we read often in the Testament [i.e. Bible]. 
Do not try to think [or brag] shrewdly

Or speak inquisitively

Be submissive in all good things

Lead each other to it.

Offer to God honour and praise

Avoid bad women

For they are rejected by Christ,

Whose name is the cornerstone. Amen. ${ }^{20}$

Beguines, and women like them, were often regarded by canon lawyers and other ecclesiastical officials as "a pernicious sort of woman;" reflecting the phrase perniciosum genus est mulierum that originates with the thirteenth-century canon lawyer Hostiensis. ${ }^{21}$

In late medieval Bohemia, women emerged from the shadows from time to time in displays of piety and devotion. Following the execution of three young men in Prague in 1412, followers of Jan Hus who were detained for protesting the sale of indulgences, women played a public role.

And one woman, most likely from the aristocratic group near Bethlehem, brought three white sheets and covered the bodies of the executed. When the people in large numbers then lifted the bodies and carried them while singing solemnly Isti sunt sancti to Bethlehem [Chapel], they were followed by ladies, mainly from the Bethlehem group, crying loudly and carrying and in solemn excitement kissing the veils, which had been used to wipe the blood of those put to death. (Císařová Kolářová 1947, p. 30)

There are rumours and occasional glimpses in the sources of women preaching, engaged in liturgical participation, and in exercising religious leadership. Inquisitorial reports suggest women heard confession and claimed the sacerdotal powers of absolution. Some Táborite women evidently consecrated the sacrament testifying they had been taught by certain Hussite priests how to do so and in consequence had actually done so on many occasions. ${ }^{22}$ John Klassen observes that if women had literally engaged in sacramental consecration then Hussite women "had entered the very heart of male clerical privilege (Klassen 1999, p. 193)." There may have been earlier precedents. On Friday to Sunday, October 3-5, 1393, Walter Brut testified before the bishop of Hereford, John Trefnant in the Hereford Cathedral claiming: "Women have power and authority to preach and make the body of Christ, and they have the power of the keys of the church, of binding and loosing." ${ }^{23}$ Was this merely a theoretical pronouncement based on an abstract theological principle? Is there any evidence that women did exercise sacerdotal authority?

Even earlier, the Bohemian servant girl Kačka came to the attention of church authorities for investigation in 1378 on suspicion that she communed frequently enough to raise concerns, that she composed her own prayers, and actually preached. It is possible Kačka may have been taught by Beguines (Tadra 1893, pp. 311-12). How many prayers did she write or, like Anna Marie Trejtlarová, was there only a single text? To whom did she preach? The sources are silent. There was either sufficient evidence or widespread rumour to cause the Council of Constance to pass a resolution forbidding preaching by women. Violators of that edict were ordered punished. ${ }^{24}$ Štěpán of Dolany, abbot of a Carthusian house in Moravia who maintained strident opposition to the Hussites, alleged that a woman wrote a book and parts of that writing were preserved in the abbot's rebuttal to the perceived threat of Hussite ideas. ${ }^{25}$ The abbot went on to complain that this unnamed woman actually mounted the pulpit in Bethlehem Chapel and scandalously addressed the congregants. Her supporters elevated her to the status of teacher (Dolany 1721-1729, vol. 4, cols. 520-4 and 534-40). Hussite women also assumed active, public, leadership in compelling action by Prague authorities when they believed the principles and practices of the revolutionary movement were under threat. Women at the royal court seem to have been sympathetic to the ideas of Jan Hus. Anna Mochova was excoriated as an infamous 
woman of dubious reputation who was so notorious her soul was declared damned to perdition. A nameless Dominican writer composed the Invectio satirica in reges et proceres viam Wiklef tenentes wherein he denounced her in strident terms as an instigator of heresy, edging her towards the even more dire rank of heresiarch. Like Anna Trejtlarová, Anna possessed significant property including an estate at Kamenice on the Lípa River, part of Hradiště, and more than half of Ústí, along with patronage of the parish (Klassen 1999, pp. 176-77). When King Václav appeared to favour Hussites late in his reign, there were complaints he had come under the evil influence of certain women (Kaminsky 1967, p. 265). Within the records of the Hussite movement, we find traces of discussions about women and political power with hints that Táborite leaders had debated the rights of women and reached some conclusions about their eligibility to govern (Pelhřimov 1430, fol. 30r). It is possible to understand this text as implying that Tábor had recently made a decision about certain women as possible magistrates. If so, that conjecture does not appear to have become practice. Heresy may have advantaged women to some extent in Hussite Bohemia, but in other ways heresy was a disadvantage. Dowries were ordered seized from women on account of the heresy of their men. ${ }^{26}$ There are three named women among the Hussites, Margaret Peruce, Katherine Vraba of Sulevice, and Anna Mochova, who used their rights of patronage to bolster the Hussite cause. ${ }^{27}$ Perchta of Šternberk supported the Hussites openly after her husband was killed at the battle of Vyšehrad on 1 November 1420 fighting the heretics. In early 1421 she declared her allegiance by embracing the "four articles of Prague" and placed her castles, towns, villages and fortresses in the service of heresy (Ververková 2021). Šternberk and Konopiště castles along with the town of Benešov came under Hussite control. ${ }^{28}$ These factors allowed women to achieve a modicum of authority and control and permitted them sufficient standing to find a voice in religious affairs. They may not have committed ideas to print but this should not be a criterion for determining influence or clarifying the scope of Reformation. Several decades later Argula von Grumbach was born near Regensburg. She was perhaps the first female publicist ever. About 29,000 copies of her pamphlets circulated. The Ingolstadt professor and canon lawyer Georg Hauer called her "a female desperado," a "heretical bitch," and a "shameless whore (Matheson 1995, pp. 2, 53-4, 19)." This was the type of invective hurled at women who exercised agency and assumed a public role especially in matters of religion. The denunciation echoes the remark made by Jakoubek that the worst sorts of errors were the purview of women. In 1416, the Council of Constance accused the Bohemian queen of aiding and abetting Hus, of hearing his sermons, of ignoring official church decrees, and preferring Utraquism over formal ecclesiastical theology. Following his election to the papacy, Pope Martin V summoned Sophia to appear before his envoy (Palacký 1869, p. 640).

Jan Hus once declared that women were more redoubtable defenders of the truth than theologians. He asserted: "I have found ordinary poor priests and poor laymeneven women-defend the truth more zealously than the doctors of the Holy Scriptures (Molnár 1985, p. 252)." Devout women were acclaimed for spiritual devotion. As noted earlier, pious women took the lead in retrieving the cadavers of slain heretics from the streets of Prague and conveying them to sanctuaries of reverence. Jan Hus addressed an important treatise, the so-called Dcerka [Daughter], to a community of women living together in Prague. We know the names of no fewer than fifteen women within this circle (See Fudge 2010). Various other women attended sermons in Bethlehem Chapel including the queen and the wives of important citizens and governmental officials. We find interesting cases when women opposed other women when they succeeded in gaining an apparent foothold in religious affairs (Kolářová-Císařová 1915, pp. 198-201).

Hussite women were also at the center of domestic disturbances. They left husbands and households to join large gatherings in the hills of south Bohemia from whence the smouldering fires of revolt fanned into revolution that eventually convulsed Central Europe and formed a gathering storm of revolution and reformation. As alluded to above, radical Hussite communities allowed women to separate from husbands and under certain 
conditions to remarry. Heretics suppressed Latin schools but taught their children, both boys and girls, in the Czech language (Noted in Přibram 2000, p. 53). Females featured prominently in the aberrant sub-Hussite sect of the Adamites and Pikarts as demonized nymphomaniacs roaming naked through the Bohemian forests though here it is likely negative images of women were marshalled to discredit unsanctioned native reforms in the Czech lands (Fudgé 2016, pp. 183-202). In a parallel to the song about the Beguines, the humanist-turned pope Aeneas Sylvius Piccolomini famously declared that some of the Czech heretical females knew the Bible better than some Italian bishops (Sylvius 1571, p. 480). It is worth considering that Aeneas was attacking elements within the Italian episcopacy more than he was praising the piety of Hussite women. Still the anecdote cannot simply be dismissed. There are other named and unnamed women who suffered martyrdom for their religious convictions within the Hussite constellation. These can be found over a one-hundred-year period from the Hussite massacres at Kutná Hora in 1416 up to the passion of Marta of Poř́či in 1527 at Prague. The theological advocacy of women and their willingness to suffer for religious conviction allows these women to achieve a public role in the history and development of Reformations. Sacrifices of faith aside, women in early modern Europe suffered because they were without power whether they were Catholic, Protestant or Hussite. ${ }^{29}$

\section{The Martyrdom of Klára the Housekeeper and Mikuláš the Weaver}

At Christmas 1526, some followers of Jan Kalenec, a Prague cutler living in the Malá Strana quarter of Prague and pastor of a small church of the Unity of Brethren, were pressured at the Town Hall to recant heresies and confess the true faith. Kalenec was initially loyal to the Utraquist church, influenced by Luther's teaching, later joined the Unity of Brethren but gravitated towards the more conservative ideas within the group. Eventually he embraced an extreme radical program sharing affinities with some forms of Anabaptist Protestantism. Around 1522, Kalenec succeeded Bishop Amos as the leader of the minority party within the Unity of Brethren. The ideas promulgated by Kalenec's group were deemed dangerous by suspicious and jittery authorities. Kalenec himself was arrested in December 1524, branded in the face, whipped publicly, than banished from Prague. He went to Moravia and continued his work at Letovice. ${ }^{30}$ Annoyed with Kalenec, concerned with heresy, and eager to control the dissemination of proper theology in the conflicting and competing streams of Reformation ideology, parish priests in Prague went from house to house rounding up suspects. This involved individuals in the parish of St. Stephen. Some of those arrested were executed while others were jailed (Hrejsa 1947-1950, vol. 5, p. 7).

Among those caught up in the repression were Mikuláš Vřetenář, a spindler or weaver, who worked on the spindle lathe and hence had his trade. Another was a widow named Klára who served as the housekeeper of his dwelling at number 479-II in Na Zderaz close to the Augustinian convent of St. Katherine and the church of St. Stephen near Charles Square in the New Town. She was in her sixties and contemporary sources describe Mikuláš as an old man. ${ }^{31}$ In 1518, Mikuláš was the owner of a house in Růžená Street (Šimák 1903, p. 655). Both were adherents of the teachings of Kalenec and both believed that confessions of faith should be voluntary and it was improper to coerce one to achieve unanimity of thought. ${ }^{32}$ Both were unwilling to submit to pressure to conform their religious beliefs to prevailing majority views. The local pastor in the immediate area, a priest named Jakub Slovák or Polák who had also served as parish priest at St. Giles in the Old Town of Prague until 1523, appears to be the individual who accused them based upon rumour and the testimony of some of their neighbours. Previously he had been expelled from the city of Kolín by its citizens, especially the burghers, because of unspecified mischief. Jakub was at the church of St. Stephen along with another priest named Jiřík Oulehle. Other sources identify the parish priest as Mikuláš Provazník. However, the latter was not appointed until 1531 (Písař 1907, p. 208, n.18 and Šimák 1907, p. 654). Raising the alarm, Priest Jakub immediately went to the administrator of the Utraquist Consistory, Master 
Havel Cahera, and recommended swift punishment for such individuals. Cahera was a prominent Utraquist priest with some questionable and possible politically-motivated connections to Lutheranism and in many respects remains a "mystery man" (David 2003, pp. 69-72). He acted in concert with Master Jan Pašek, who served as mayor of Prague between 1524 and 1528, as the main forces aimed at regulating religious practice and curbing dissent.

Our main source for these events is a chronicler. Bartoš the Scribe (1470-1535) worked as a scribe and cloth merchant. He was a committed Lutheran who had been expelled from Prague between 1524 and 1529. Upon his return, he composed his Pražská kronika od léta Páně 1524 do konce léta 1530 (Prague Chronicle from the year of the Lord 1524 until the end of 1530) in the years between 1530 and 1534. The chronicle is valuable for its coverage of the dramatic events that occurred under the ethos cultivated by the city mayor Jan Pašek that produced a severe repression of the Unity of Brethren. The chronicle does not follow the tradition of chronological reporting but engages in detailed elaboration and is generally reliable. ${ }^{33}$ The chronicle of Bartoš the Scribe is not strictly history, but more accurately a contribution to the genre of apologia. Nevertheless, for the turbulent events in Prague between 1524 and 1530, it is a valuable source no less so for its collection of valuable material that otherwise has been lost. The chronicler provides the testimony of one member of the people of Prague. In this witness, he "perfectly reflects the mood of his time and one level of the population (Šimák 1903, p. 670)." We possess a second account of these events, the so-called Paměti o bouřri Pražské roku 1524 (Memories of the 1524 Prague Storm), but it is a "rather mysterious source." It is far less coherent than the account provided by Bartoš the Scribe. The writer appears to have been present at the relevant events but the account is marred with basic errors. For example, the incorrect year is given, 1524 rather than 1526, the identity of the pastor in question is confused, the author does not know where Klára lived, and he is wrong about who the sitting mayor was despite the latter's prominence. While there is indication of eyewitness evidence, it is likely the work reflects several authors and "not the work of a single person." It is not possible to attribute any of the text to Bartoš the Scribe. ${ }^{34}$

Bartoš the Scribe asserts that Klára and Mikuláš went along with their pastor and were sold to the children of the Praguers. Like Judas who sold his master they fetched one of the thirty pieces of silver. ${ }^{35}$ This curious and convoluted sentence suggests that Klára and Mikuláš were betrayed by their pastor. He was the informer. In consequence, the two were charged, imprisoned, and later faced interrogation before the Consistory in the Town Hall. Confronted but consistently contumacious, they endured a year-long detainment. Confinement in a dungeon did not persuade them to recant and the authorities had no further luck when the two were subject to rigorous interrogations. Those examinations occurred in the presence of the administrator and the Consistory.

Once the administrator, the Consistory, town officials, including the mayor, elders of the community, and representatives from both the Old and New Town municipalities of Prague were assembled, the prisoners were brought from the prison and appeared in the common room. Cahera and the assembly of councilors and priests questioned the prisoners. There were eight queries put to them. ${ }^{36}$ The main focus was on the eucharist. Did the accused believe that Christ was truly present in the sacrament? The more radical elements in the Hussite tradition absolutely opposed the Roman doctrine of transubstantiation and generally dismissed the Lutheran understanding of consubstantiation so it came as no surprise when Mikuláš confessed he did not. However, he asserted that wherever a faithful priest met with a congregation of people the word of God was the true supper of the Lord. He went on to assert that if a proper understanding of the eucharist "were to be in the sense you suggest, something else would have to be introduced that Christ did not prescribe ... we do not believe in it (Písař 1907, p. 209)." Klára agreed. The second matter related to the intercession of the Virgin Mary. The accused confirmed they knew of no scripture suggesting this to be the case and summarily concluded: "She does not intercede 
(Písař 1907, p. 210)." The Consistory then wanted to know if Klára and Mikuláš believed that saints interceded for Christians. Mikuláš answered:

I hold to them and believe they have been chosen by God, by the grace of God, and by the mercy of his foreknowledge of eternal life. They are dear friends of God, some of whose bodies have been burned or [otherwise] destroyed. They will be restored in judgment and in time shall be glorified in the coming of Christ. But I also hold that they do not intercede for us because their souls have not yet been connected to their bodies and they cannot speak. (Písař 1907, p. 210)

This response reflects certain streams of medieval thought represented in Aquinas who held that the disembodied soul cannot speak. Naturally, this does not mean that one cannot understand, and it does not address notions of will, and so on. ${ }^{37}$ No discussion followed this statement so the prosecution moved on. The court then wanted to know what the defendants believed about St. Paul. Those on trial affirmed he was a "special apostle" who had been chosen by Christ. ${ }^{38}$

The questions then turned from theological matters to issues surrounding the leadership of certain religious movements. It is possible to detect suspicion about the more radical forms of the Hussite tradition that persisted into the sixteenth century. The essential context relates to politics that tended to favour certain religious practices but excluded others. The Peace of Kutná Hora (1485) forbade either Catholics or Utraquists from suppressing the other. This related both to secular as well as spiritual matters. Both were admonished to practice toleration and sympathy for the other. Both were permitted to practice the faith as their tradition saw fit, and enjoined to refrain from calling the other heretical. No one, either Catholic or Utraquist, was to suffer discrimination because of religious preferences. Neither body should attempt to expand their sphere of influence, and parishes and churches were to remain as before. ${ }^{39}$ There was no consideration extended to the Unity. The St. James Day Mandate (1508) reinforced recognition of the Utraquist Church but did not provide legitimation for the Jednotá bratrska (Unity of Brethren) (Palacký 1840-1872, vol. 6, pp. 391-93). If Kutná Hora was silent on the Brethren, the St. James Day Mandate provided the basis for legal repression. Churches belonging to the Unity were ordered closed, meetings outlawed, books promoting Brethren theology confiscated and destroyed, sympathetic printing presses shuttered. Priests belonging to the Unity of Brethren were remanded to Prague for the correction of their troublesome teachings. There were penalties provided for noncompliance. Recalcitrant members were ordered imprisoned, those refusing to join either the Catholic or Utraquist churches were in danger of expulsion from the land, those providing aid and shelter were liable to be fined. The provisions of the St. James Day Mandate were familiar to the authorities who detained Klára and Mikuláš.

The Consistory quizzed the prisoners about Lukáš Boleslavský. Brother Lukáš was a bachelor from Prague who served as the head and spiritual leader of the second generation of the Hussite brethren and was a premier figure during the time the Unity of Brethren split into two main groups in $1490 .^{40}$ Mikuláš affirmed that Lukáš was a good man but the accused did not endorse his views concerning other Czech Christians. This refers to quarrels persisting between the two parties within the Unity of Brethren and the ongoing strife between Lukáš on one hand, Amos and Jan Kalenec on the other. However, Mikuláš insisted: "I don't judge him, may the Lord God judge him!" What view did the accused hold about Brother Matěj? This individual was considered "a holy man who is good, but imperfect." ${ }^{41}$ Of Jan Kalenec, the Consistory heard from the deponents that "he was a man having the grace of God, and a martyr for the truth of God and of Christ" who was responsible for sharing with the prisoners "the knowledge of the law of the Lord Christ (Písař 1907, p. 211)."

Lastly, the Consistory desired to learn how many priests of similar persuasion were active in Malá Strana (the Lesser Town); a Prague quarter on the left bank of the Vltava River. Mikuláš said there were four priests (Amos, Kalenec, and Jan Cvilda) adding his name to that number noting he was licenced to preach but not to engage in sacramental 
ministry. The Consistory wanted to know why. Apparently, when he was young, Mikuláš referred obliquely to a relationship with one of the Roman priests who mistreated him. He later confessed this matter to his colleagues and they determined that he should not undertake the administration of the sacraments.

They asked him: "Why do you not serve the sacraments?" He said it was because "in my youth I was with a priest from your gang of papists and he used me in an evil way. About this thing I confessed to my brethren, who for that reason afterwards did not allow me to dispense the sacraments." And he immediately then begged those who stood around, saying: "Dear good people, if you have your own children, do not give them to the priests, since they surely will use them in an evil way, and nothing good will become of them, because of the way they train them". (Písař 1907, p. 211)

What does this means? Why should Mikuláš have been limited in his pastoral functions? Understanding this situation sheds light on factors of church discipline, the positioning of the Unity with respect to canon law and aspects of medieval theology. The partial sanctioning of Mikuláš reveals affinities with religious tradition and an inability to transcend those categories even within heretical movements and breakaway sects like the Unity of Brethren. This propensity has implications for the social and religious limitations women had to struggle against. More significant are considerations of morality that represent one degree of separation between radical Hussites and the Latin church. Explaining and situating this aspect of the trial also sheds light on what is a remarkably rare instance in historical records especially in a court proceeding devoted chiefly to matters of religious doctrine.

\subsection{Sodomy and the Sacraments: A Curious Interlude}

While this legal sidebar has nothing to do with women and Reformations directly, the interrogatories at this stage of the hearings are frustratingly vague and demand some comment. The allegations levelled by the defendant cannot easily be construed as overt anticlerical sentiment but suggests more serious matters. The nature of the relationship must have been sexual and regarded by the Brethren as an irrevocable contamination that precluded Mikuláš from celebrating the sacraments. Official ecclesiastical views from the medieval period regarded sodomitical practices as activities that polluted. Sodomy, in its various definitions, carried with it rare and lasting stigma. Late medieval authorities also observed that when young boys were initially introduced to such debaucheries they were essentially ignorant of what exactly they were participating in (Puff 2003, p. 69). There were notorious cases involving the clergy and the sin of sodomy. There is the striking case of Johannes Stocker, a cleric on the staff of the Basel Cathedral. In 1475, he confessed to being both priest and sodomite. This was because of his relationship with a young student and choirboy. Stocker was arrested and charged. He admitted to sexual relations with the young man occurring in the cathedral precincts no fewer than fourteen times. Stocker was sentenced to perpetual exile. ${ }^{42}$ The eleventh-century Peter Damian proscribed severe penalties for those engaging in such behaviour noting specifically that sodomy should preclude men from engaging in sacramental ministry on the grounds that since "sodomy is comparable to homicide, the bloodstained hands of a sodomite cannot licitly perform the sacrament." 43 The understanding of sodomy became elevated into a preoccupying sin and thereafter into a capital crime that ranked with homicide as the most heinous of human infractions of divine morality. ${ }^{44}$ Sodomy was thought capable of contaminating both body and soul. The transgression was so egregious that it was believed it could scarcely be possible either to repent of it or obtain forgiveness. ${ }^{45}$ This is because the offense is a sin against God and so dire that it expels divine grace from humans. Medieval theologians were convinced that certain sexual sins were so "terrible and improper" that offenders could not engage with the sacraments (Hus 1975, vol. 1, pp. 251-55). Canon law took the same perspective. Book twenty of Burchard of Worms' Decretum declared that a cleric who seduced a boy (parvulorum) or young man (adolescentium) or was sexually involved with one ought to be defrocked, publicly beaten, placed in manacles, and imprisoned. Then the 
offender was remanded to a monastery for the remainder of his life under supervision. He was never again permitted to have contact with young men (Worms 1880, vol. 140, book 20, c.19.5, col. 925). Others believed that offenses attracting rituals of degradation and public penance ever after excluded those involved from holy orders (Blum 1992, pp. 29-30).

Mikulás noted that the interference occurred when he was young. The definition of childhood is notoriously imprecise and during the early modern period we find instances wherein individuals up to the age of twenty-five were regarded as children. ${ }^{46}$ Mikulás may have been a young man in his late teens and consented to the advances of the Roman priest or he may have been a pre-pubescent boy forced into something he misunderstood or even resisted. The distinction today would make a great deal of difference but that point does not appear to have arisen during the hearings before the Prague Consistory in 1526. Latin canon law included censures for sexual sins and sodomy is a prominent concern (Tentler 1977, pp. 141-42). Medieval theology and canonical legislation provided ample justification for the Brethren to exclude Mikulás from performing the sacramental duties of an ordinary cleric. While medieval canon law had no binding appeal on the dissident Hussites, principles of morality did and even though Mikulás had repented of his illicit dalliance he remained ineligible to preside over the channels of grace provided by the church. ${ }^{47}$

The fact that Unity church leaders were unable to overlook the mistreatment of the young Mikulás and in consequence forced him to curtail his pastoral activities presents a parallel to the occasional progressive recognition of female agency that simultaneously and ironically could not allow some people on account of their gender to truly transcend humanly-constructed social and religious limitations.

Following this interrogation sidebar, the court did not respond specifically to the statements made by the deponents but instead admonished the prisoners to give up "all of their delusions." When Mikuláš rebutted that invitation, they characterized him as a "false prophet" for having suggested that priests misused young men. ${ }^{48}$ It is unfortunate that additional detail does not appear to have been recorded or preserved. During the interrogation, the defendants spoke openly before the court, arguing on the basis of the law of God. Klára and Mikuláš demonstrated firm and consistent knowledge of the law of God and such proficiency in the Scriptures that it was a wonder to the common people. The condemned were undeterred by the threat of death and controversially asserted that many of the priests were a duplicitous gang of thieves, hypocrites, sodomites, and workers of other abominations. When the priests in the court failed to overcome the witnesses with argument or admonishment, the two were condemned to death by fire. The people of Prague apparently consented to the sentence. Having been condemned to suffer capital punishment as heretics, the prisoners were bound over to the mayor's office into the safekeeping of Jacob Kocura, a bachelor from Porričć, and Martin Smil, the butcher. ${ }^{49}$

\subsection{The Heretics and the Knight}

Even though the recalcitrant prisoners had been remanded to the stake and were quite aware of the fate that awaited them, they did not waver in their faith. The chronicler, Bartoš the Scribe, tells his readers that an unusual incident then occurred causing "you to read with wonder" (Písař 1907, p. 212). Through exemplary perseverance, while on their way to the pyre, the two martyrs apparently gained for their faith a new convert. During the vigil of St. Thomas, Klára and Mikulás were consigned to the stake. On the street between the prison and the pyre, the convicted heretics encountered a man named Hynek Perknovský who belonged to the order of the knights. Lord Perknovský apparently came from Jičín though this may be erroneous since the Perknov family was established at Turnov. Perknovský had a house in Prague near the place of execution and this may account for his sudden appearance on the street during the journey to the stake. ${ }^{50}$ As the condemned were led to their deaths, Mikuláš sang a song while the biřič [bailiff or constable] loudly proclaimed the reason for the execution: "The heresy of this heretical Mikulás is speaking blasphemous things about the holy body and blood of the Lord Christ. 
He has been warned about these delusions." Since he refused correction, the path to the pyre was the only appropriate remedy because both he and Klára "have become useless [or recalcitrant] in their delusions and have refused to depart from them" (Písař 1907, p. 212). This was contumacy; the core of heretical depravity which was even more dire than errors of theology or dogmatic misapprehension.

At this dramatic stage, Hynek Perknovský appears in the narrative. According to one account, he asked the bailiff: "Dear neighbour, why should such a death happen to this man and to this woman?"51 He was informed this was the consequence of stubborn adherence to heresies. Lord Perknovský asked permission to speak with the prisoners and was given leave to do so. He approached the condemned and asked both of them if they believed anything against the Christian faith. When Mikuláš said he was not oppositional to the common Christian faith, Perknovský posed a variety of questions. These included: “Do you believe in the Lord God? Do you believe in his Son, Jesus Christ? Do you also believe in the Holy Spirit? Do you believe in the Holy Trinity, that is God the Father, his dear Son, and the Holy Spirit?" The questionnaire reads like a catechetical review and resembles standard queries raised around specific periods of spiritual formation. Mikuláš confessed agreement: "I believe and in that faith I wish to die." He then professed his faith in a loud voice: "I believe in one true God, threefold in persons. I believe in God the Father, Jesus Christ his Son, even in the Holy Spirit. I believe according to the general Holy Church and the Christian faith." Perknovský must have surprised all within hearing when he suddenly and dramatically announced: "In that faith I too wish to die and go with you to the stake today for I believe as much as you do." 52 This created an immediate and sensational uproar. Many shouted that Perknovský was an impertinent rogue who had taken to defending and encouraging the condemned scoundrels. Perknovský was unmoved and went farther to affirm the Eucharistic conviction of Klára and Mikuláš that Christ was not physically present in the hands of priests during Mass but was instead in heaven at the right hand of God the Father. He declared: "I also believe that Christ Jesus is in heaven on the right hand of his Father." These public declarations of alternative views of Eucharistic theology were inflammatory and deemed dangerous to simple pious minds. While he continued to speak, the mayor ordered him taken into custody forthwith and "the people tore him away from the heretics." The crowd demanded that this friend of heretics should be burned as a villain too since he supported the two heretics in their "delusions" (Písař 1907, p. 213). In consequence, Lord Perknovský was immediately imprisoned. Upon examination, the major apparently told Perknovský that Klára and Mikuláš had been condemned, not by city authorities but instead by the priests. The new heresy suspect was then led to the Town Hall along with other prisoners for interrogation.

Three weeks later, Lord Perknovský was transported to Prague Castle where he appeared before the lords because at that time there was an assembly of the Bohemian Land Diet (Česky zemsky sněm) in session and there was a great deal of talk about him and the incident that occurred wherein he spoke with the convicted heretics. Eventually he was sent to Lord Zikmund of Smiřický and Lord Ješek Strojetický and they asked him to confirm what he truly believed about the sacrament. His confession appeared to satisfy them when he confirmed that he did in fact believe that the presence of Christ was in the bread and the wine when consecrated by a priest. Taken at face value, this appears to be a different statement to what he made to the condemned heretics. Despite this apparent affirmation of orthodox theology, other factors prevented his release because he remained incarcerated for two years. According to the chronicler this was because "he had always been withdrawn from King Ferdinand" (Písař 1907, p. 214).

\subsection{Klára and Mikuláš Stand Firm}

Meanwhile, the travails of Klára and Mikuláš continued. Following the spirited exchange with Lord Perknovský, the procession continued into Celetná Street near a depiction of the crucifixion painted on the wall of a house where some Beguines lived. As they made their way to the end of their earthly journey, both Klára the housekeeper and 
Mikulás the weaver remained true to their convictions. They truculently refused to bow to their tormentors, which was the duty of convicts, and declined to adore a crucifix. The mayor halted the progress and admonished the condemned to kneel before the painting as other criminals customarily did. The heretics refused: "We will not kneel before this painting, but only before God in heaven." The mayor said to them: "Although this is only a painting, it is a sign of the passion of God, how the Lord Christ was led with thieves to be executed, and it is a sign of the cross of Christ," and repeated the suggestion they kneel. Again, Klára and Mikuláš demurred arguing they had no need of such symbolism because they held the true sign of the cross of Christ in their hearts. In exasperation, the mayor retorted: "Look how stubborn you are and even now you do not want to leave off your blasphemous words." The two heretics answered: "Let us at least now during our last hour have the freedom to speak the truth, for you intend to deliver us to death for it." ${ }^{\prime 53}$ Mikulás sang and spoke cheerfully to the effect that this was the way all martyrs were delivered to death for the testimony of Christ. They were brought through the Mountain Gate (Kutná Hora Gate) and beyond the city walls. The route led to the King's Court into what is today Celetná Street around the Powder Gate to Hybernská Street. For the third time officials shouted at them to show obedience. Approaching another depiction of the passion of Christ, the mayor again ordered them to kneel. Mikuláš asked: "Where is the Passion of God?" He was told it was painted on the pillar in front of him. Mikuláš replied he did not recognize an image as reality. The heretics contumaciously pointed out that scripture indicated it was improper to make graven images. This confrontation mirrors earlier debates within the Hussite movement and reflects ongoing controversies that continued to convulse the Reformation world of the sixteenth century ${ }^{54}$ Klára and Mikuláš did finally kneel but away from the painting. The official Jiřík Komedka objected. The heretics took no note of this but turned their backsides to the pillar, possibly in a deliberate contemptuous posture. Looking up to heaven they humbly prayed: "We worship the Lord God himself and in the name of Jesus Christ who redeemed us we kneel." ${ }^{55}$ This could be seen as another rejection of civil and ecclesiastical authority. Having prayed they professed their faith. Then they blessed their children who had escorted them, the daughter of Mikulás and one of the daughters of Klára. The latter said: "Dear children, we commend you to our dear Lord God to keep you in his will." At the same time, they gave their daughters good admonition without fear. "Many of the people were astonished and hearing them were moved to tears." The daughters blessed their parents and went back into the city in tears. ${ }^{56}$

Having been delivered to the sixteenth-century Czech "Pharisees and Sadducees," when they came to the stake that had been prepared for burning, the executioners removed the shoes from the condemned. Neither shrank from the moment. Mikuláš stepped up boldly and cheerfully looked up to the sky and prayed:

Lord Jesus Christ, son of the living God, who was born of a pure virgin, who endured the death of the cross for me who was poor and sinful, you suffered and rose from the dead. I worship and pray to you, and to no one else; have mercy on me and forgive my sins! Almighty, eternal God! I give thanks to your holy grace, that you have brought us forth as the father of this world, and have rewarded us and guarded us all the days of our lives and considered us worthy to come to this place for your name's sake. We also faithfully believe that we will feast in your grace today giving up these corporal and worldly things, that are nothing but hardship, misery, filthiness, and sin, for the crown of glory. (Písař 1907, p. 216)

Theological concerns continued to prevail. Číča the butcher addressed Mikuláš: "Is the presence of God not in the church?" The captive agreed noting God is everywhere and divine authority is not limited and the dominion of God is forever. There were some standing nearby who agreed with these statements but also admitted that if faced with burning at the stake they would deny their convictions (Šimák 1907, p. 341). Klára gave no indication she was having second thoughts. As the executioners prepared the condemned for death, another prayer was offered: 
Almighty God, who lives perfectly in the Trinity, God the Father, Christ Jesus, his dear Son, also the Holy Spirit, look upon us at this hour, and in your holy grace receive our souls. Look unto our enemies, how they have increased against us and have hated us with false hatred; look upon them, dear lord, and let them come to know your faith and your truth, that they may walk in the ways of your truth. We also pray for these who have condemned us to death through ignorance. Forgive them, dear lord, for they do not know what they are doing. Just as St. Stephen prayed for his enemies, so we pray to you. (Šimák 1907, p. 341)

Then the defendants knelt down, and Mikuláš began to speak loudly in Latin the verse: "I put my trust in you Lord, do not let me be confounded in all eternity." As he finished, the executioners tied his arms and legs cruelly to the stake but he sang even more and willingly and piously recited the Latin Psalms: "Remember your mercies, $\mathrm{O}$ Lord; and remember your lovingkindness unto me for thy goodness sake, O Lord. O my God, preserve my soul, I shall not be ashamed: for I have trusted in thee; do not curse my soul with sinners and the blood of my life with men whose hands are full of iniquities" (Písař 1907, p. 216; Šimák 1907, p. 342).

Klára also stood at the stake and offered encouragement to Mikuláš admonishing him not to fear death but to remain steadfast and stand ready to die for the truth of Christ. Then observing some people chasing, beating, and pushing some Jew, she said: "Dear God! You do not leave the Jews in peace, even though they believe far better than you" (Písař 1907, p. 216). She was tied to the stake and Mikuláš admonished her to pray as he had but she said: "How should I pray, when they tied me up so tightly so that, I believe, they broke both my arms, since I, as a woman, cannot bear it as stoutly as a man? And so that he may know that I have already commended myself to my dear God, and I do not cease to pray to him in my spirit and in my heart" (Písař 1907, p. 217). Then she addressed her fellow martyr for the last time: "Dear Mikuláš, may you also pray for me to the Lord God." Mikuláš consoled her: "Don't worry anymore, dear Klára." After these words, the executioners set about their work. A contemporary account captures the ethos of the moment with these brief exchanges and the climax of their suffering. "The executioner then immediately, having jumped down from the pyre, took the books of that certain Mikulás out of a bag-what they were I do not know-divided by sheets of cardboard so that they would appear more numerous, dumped some on his head and others on his belly, yelling: 'Hand here trachtarum, trachtarum [some quasi-magical incantation like Abracadabra?],' and immediately lit the torch and inserted it under the pyre" (Šimák 1907, p. 342). Hence, their offensive books were consigned to burn with them and they were condemned to perish in the flames with the same books from which they had derived strength while alive. ${ }^{57}$ The two continued to pray so that everyone who stood nearby could hear. The condemned encouraged each other declaring their readiness to die for Christ. During their silent prayers, Klára breathed her last while Mikuláš recited the Creed and sang psalms in Czech and Latin. It is noteworthy that both mounted the pyre cheerfully. The end of these willing martyrs was dignified and brave. The chronicle of Bartoš provides summary comment: "They went to their death with a firm mind and much joy, piously singing Christian songs, and they stood there and persevered to the end as a confession of their faith ... And so, without any shouting or making a fuss, both of them fell asleep" (Písař 1907, pp. 208-17; Šimák 1907, pp. 339-42). They perished on 9 December 1526. The singing of heretics is not unusual. Both Jan Hus and Jerome of Prague sang at the pyre. The practice forms part of a broader martyrological tradition (Joldersma and Grijp 2001, pp. 21-27).

The anonymous writer concludes his narrative of the life and death of Klára the housekeeper and Mikuláš the weaver with a summary declaration:

All of these things had been foretold by the Lord God to his disciples and to their descendants that false prophets would arise and deliver them to schools, to prisons, to rulers and kings, and to kill them, and to hate them all for his name, to chase them out of the villages while affirming that whoever kills them will 
think they are serving God. Then it shall come to pass, when it is certain, that this prophecy ... [will come true] that in his own time [the Lord] will not allow a temptation more than we can bear ... to whom in the Trinity, blessed be God the Father, Christ Jesus, the Son of his beloved, and the Holy Spirit, be honour, power, strength, empire, glory, clarity, and thanksgiving for the ages. Amen. (Šimák 1907, p. 342)

The story, grounded in theological conviction and the crown of martyrdom featuring an example of female agency, entered the historiography of the Unity of Brethren and was immortalized in the work of the last bishop of that movement (Comenius 1648, pp. 105-7). Moreover, it is not without significance that the famous Jena Codex bears witness to the passion of Klára and Mikuláš. Marginalia in the incunabulum clearly refers to their execution: "1526 fleria] q[uarta] an[te] n[a]ti[vi]t[atem] X[pisti] Bratra mikulasse czlo[wie] ${ }^{k a}$ ssediwe $[h]^{\circ} z$ starau babkau vpalili w praze statecznii oba rytirzi z milosti pa[n] ${ }^{a}$ gezisse byli a wiru zachowawsse zemrzeli w Kristu." ["In 1526, four feast days before the nativity of Christ, Brother Mikuláš, a gray-headed man, with a little old woman, were burned [to death] in Prague. Both of these brave knights were in the grace of the Lord Jesus, and retaining their faith they died in Christ."] It is possible that Hynek Perknovský was responsible for the notation. Perhaps equally significant is that the four-line marginalia appears above a coloured woodcut depicting the death of Jan Hus suggesting that the writer consciously linked the deaths of Klára and Mikuláš with that of Hus whereby forming a clear relationship between both events around the theme of defending truth. ${ }^{58}$

\section{Marta of Poříče}

The priest Jakub Slovák's door-to-door search for suspect Christians garnered more victims. The two martyrs, Klára and Mikuláš, were supported by Marta of Pořiče, a prominent woman from the diocese of St. Klement, who strengthened them in their steadfast intransigence. ${ }^{59}$ Marta was taken into custody by the people of Prague, accused of adhering to the same beliefs as Klára and Mikuláš and she followed them to the stake a year later. The repression was the work of Catholics and Utraquists in the spirit of Jan Pašek of Vrata, a Catholic who served on the joint Prague city council, and Havel Cahera who was the preacher in the Utraquist Týn Church in the Old Town (Fudge 1996, p. 76). The two "maintained a rule of terror" for four years (Heymann 1968, p. 121). The Protestant theologian and church historian Ferdinand Hrejsa observed that such "enthusiasm for persecution met with public opposition, which saw and admired the piety of those convicted" (Hrejsa 1947-1950, vol. 5, p. 7). It may be observed that Marta acted "as if the spirit of the former Táborite sisters had come to life after a hundred years" (Císařová Kolářová 1942, p. 254). This is a remarkable allusion to the earlier revolutionary period when Hussite women gained prominence for their activities and staunch advocacy of Hussite religious practice. Marta of Pořičce is an otherwise completely unknown woman who has gone down in history remembered for her suffering and heroic death. It appears she was more independent and outspoken than Klára, who was clearly under the influence of Mikuláš and the latter is more prominent in the chronicle account of Bartoš the Scribe. Like Klára and Mikuláš, Marta was versed in the Scriptures and eloquent in controversy and in the end was steadfast in suffering. Her appeal to Scripture was an open challenge to prevailing religious authority. Two decades later in England, Anne Askew told Bishop Edmund Bonner in 1546 that she believed whatever the Holy Scriptures agreed on (Beilin 1996, p. 60). Feminine appeals to Biblical authority in the face of ecclesiastical power were especially offensive to clerics, inquisitors, and theologians. Marta of Poříče had previously lived in the Madírkov house near St. Klement's and she too elaborated her "delusions" before the Consistory having been handed over to that body by the lord mayor of Prague for the correction of her errors. Marta's confession from 1526, was published in the records of the Consistory and the archives of the archbishop, but under the misleading reference: Marta "revokes" her heresies ("Marta odvolává před konsistoří své bludy"). It is from these records we learn that Marta was from the Madírkov house at St. Klement's (Borovy 1868, p. 32). Affirmation 
of Trinitarian doctrine continues to be prominent. Though confessing her belief in the Trinity, Father, Son, and Holy Ghost, and that the words of Christ were true and words of eternal life, she was unwilling to submit to consistorial authority preferring to adhere to the law of God.

As with the previous trial, Marta affirmed official church doctrine that the body of Christ remained at the right hand of God in heaven but unlike the Roman and Utraquist churches refused to admit that Christ was present in the sacrament. This doctrinal perspective is the same as that articulated by Klára and Mikuláš. Marta defended Utraquism, communing in both bread and wine, and insisted she had been properly communed: "I received holy bread and holy wine from the priest Jan Kalenec" whom she regarded as a holy person ("člověk svatý"). She refused to be communed by other priests claiming they were wicked and unworthy sinners. Marta had initially been in the town of Louny but more recently had continued to adhere to her faith over the previous four years guided by Jan Kalenec whom she insisted represented a superior form of the faith. This included an essentially symbolic understanding of the sacrament (Borovy 1868, p. 32). Again, this would not have met with the approval of Catholic, Lutheran or Utraquist theologians. Marta confirmed she was unwilling to believe otherwise with respect to the eucharist. "It was unusual," the chronicler of her death noted, "the nature of the courage, boldness and persistence when she spoke before the masters of the Consistory in the Town Hall. It was not only beyond the nature of the female sex, but on the other hand, it also surpassed many men in this. When the administrator spoke to her telling her to prepare her dress for being burned by fire, she replied even more forcefully and courageously saying: 'If she wants anything it is not just a dress but also readiness to put on her cloak saying she was ready for anything'"' (Písař 1907, p. 219). A variant version attributes the admonishment as coming from a Utraquist cleric who visited Marta in prison during her year-long incarceration (Demetz 1997, pp. 174-75). The administrator was outraged and his fury caused him to determine Marta should be destroyed. It was around this same time that Argula von Grumbach was denounced as a "heretical bitch." The epithet might easily have been pronounced against Marta by the Consistory. According to the chronicler, Bartoš the Scribe, she was returned to custody and "remained there constantly in that prison for fifty Sundays, counting the day of the burning of Klára and Mikuláš" (Písař 1907, p. 218). During that incarceration, Marta resisted a great variety of enticements to submit to the examining authorities along with "threats from the priesthood" all seeking to cause her to change her mind. "Because she was powerful in speaking, she overcame all of them with the divine scriptures." Twenty years later, Anne Askew told her interrogators: "It was against St. Paul's learning, that I being a woman, should interpret the scriptures, specially where so many wise learned men were" (Beilin 1996, p. 54). Anne Askew may have simply been modest. ${ }^{60}$ Marta felt no similar reservation. Her accusers became more and more angry with her to the point of outrage, but they could not overpower her and thus consumed with blind fury the chronicler argues "they were so much the cause of her death they were prepared to carry her boldly on their backs" to the fire (Písař 1907, p. 218). Some wondered if Marta might recant but she was resolute: "Do not worry about me for no one can bear it for me, either fire or water, whatever the Lord God allows" (Borovy 1868, p. 32).

On the Wednesday, St. Barbara's Day in 1527, Marta's testimony was put to the test. The examination by Consistorial officials, including the doctors of the university, failed to dissuade Marta from her beliefs. This offended both Roman and Utraquist Churches. The chronicler records the court was outraged with her "masculine" defense and truculence. When threatened with the fire of the stake, Marta said she was ready to be taken whenever it pleased the court to do so. Seeing there was nothing more to be done to persuade her from her position, the sentence was immediately announced. She was summoned from prison in preparation for execution. According to the custom of the time, her guilt against the assembled people was confirmed as theological: She had blasphemed the sacraments, because she did not believe that the body of Christ was in the sacrament. 
This constituted the same intolerable offense that took Klára and Mikuláš to the stake a year earlier. Moreover, she admitted she had been baptized a second time by Jan Kalenec because her initial baptism had been performed by an unworthy priest though it should be noted that Kalenec himself actually favored the practice of adult baptism. Marta also testified that she had been communed by him in both kinds and the cup, a court exhibit, was shown to the people. The death march began.

The bailiff walked ahead of her announcing to the townspeople that Marta had been condemned to die, first for blaspheming the Holy Sacrament and refusing to believe in the divine presence in the eucharist, second that she was guilty of rebaptism, and third because she had received the chalice from Jan Kalenec. ${ }^{61}$ Marta objected to the allegation about the eucharist and explicitly denied the charge explaining to those standing nearby that she was condemned because she did not want to profess false ideas along with wicked priests. Here we detect another clear challenge to authority. The idea of transubstantiation was repugnant to many alternative Christian religious movements, the Táborites before her and condemned heretics after her. Anne Askew put a fine point on the matter in her rejoinder to her judges in 1546: The bread in the eucharist is "only a sign," and a "remembrance of his death" (Beilin 1996, pp. 103-4). Marta's eucharistic sensibilities, reflects the core component of Hussite theology and for more than a century women had particularly embraced the spirituality of sacramental practice. We know of women who sometimes communed twice a day (Fudge 2020, pp. 124-25). Raising her voice to be heard by the crowd Marta said: "Dear people, this is untrue. Do not think that I should suffer such an abominable death for this. I have been condemned because I will not confess in order to please the priests that Christ, with his bones, hair, sinews, and veins, is contained in the Sacrament." Indeed, she argued, Christ remains at the right hand of God and from there will come to judge the living and dead. Marta insisted that scripture did not support a doctrine of bodily presence of Christ in the sacrament. Rising to a polemical pitch she declared: "Those who believe otherwise are all fools." This must have stabbed the clerics and theologians. Raising her voice even higher, she warned the people not to believe such priests, who were unworthy. She reminded the crowd that no good person should believe such men for there was no goodness in them. "They are all liars, hypocrites, thieves, sodomites, ruffians, and seducers." This is virtually a verbatim restatement of what Klára and Mikuláš asserted a year earlier. The reference to sodomy may have some relation to previous testimony offered by Mikuláš. Marta confirmed her rebaptism at the hands of Jan Kalenec stating she repudiated her initial baptism because of "priestly nuisance or wretchedness." It is worth noting that Kalenec and some of his followers later embraced an anti-Trinitarian theology as well as the anarchist pacifism of Petr Chelčický (Brock 1957, p. 250). Unable to tolerate such insolence, Marta was immediately ushered outside the city gates.

Coming to the place where she was to die, outside the New Town near the Mountain Gate (Kutná Hora Gate), one of the officials admonished Marta to kneel before some paintings that were there. These were doubtlessly the same ones presented to her heretical colleagues. Like them, she refused and turned her back upon these images. Her god, like that of Klára and Mikuláš, was in heaven where she turned her gaze at the last moment. Looking towards the sky she said: "It is up there where the true God dwells and it is there where we ought to direct our attention." She turned her back on a church as she walked to the stake and refused to acknowledge the institutional church. She did not hesitate to mount the pyre. Bartoš the Scribe puts it this way: "Thus she went on that journey cheerfully and piously, walking merrily, constantly praying to the Lord God, without any longing until her last hour. And so she came to her end and cleansed her life with fire at the stake." The executioner also burned a wooden chalice with her, from which the priest Jan Kalenec sometimes served her and which had been shown to the court as evidence of her heresy. She endured the torment of the fire with great courage. She was burned for her faith on 4 December $1527 .{ }^{62}$ The wooden chalice had evidently been made by Kalenec on a lathe and may have been one of many that he distributed privately to various people even though he had no proper ecclesiastical title, was not properly ordained and in 
consequence lacked the anointing and tonsuring of the Roman bishops (mazází pleše od biskupův rímských). All of this was irrelevant to the defendant: "God consecrated him to the priesthood" (Borovy 1868, p. 32; Písař 1907, p. 219). The cup was taken from the priest and the hangman put it into the fire with Marta and both were burned.

In the aftermath of this violent repression, many adherents and clergy of the evangelical churches left Prague and took refuge in the countryside in hopes of saving their lives. The persecution of the Minor Party of the Unity eventually caused its extinction. But the story of Marta was remembered (Comenius 1648, pp. 107-8). Modern writers have observed: "Few countries show in its history as much heroism and devotion to the faith as Bohemia" (Nováková 1891, p. 158). The records of their passion help to make visible these otherwise obscure women. The fifteenth-century Observant Dominican reformer Johannes Meyer's Buch der Reformacio Predigerordens is a chronicle that brings attention to the female dimensions of Dominican reform. Meyer casts sufficient light upon these women to cause them to become visible in the otherwise deep darkness of the (female) late medieval world. He accomplished this both by preserving their stories but also by identifying the women who played a role in inaugurating and sustaining the reform. He points out: "I have recorded here the names of these thirteen devout mothers because they were the holy foundation" (Meyer 2019, p. 68). The history of the European Reformations must take into account the meaning and contribution of women like "Klára and Marta of Pořiče on their way to their fiery Calvary." (Císařová Kolářová 1942, p. 32).

\section{Conclusion: What Do Women Tell Us about Reformation?}

Regardless of the fleeting glimpses we catch of Hussite women, such as Klára, Marta, and Anna Marie, in the shadows of the past there is no reliable way we can possibly know the thoughts or emotions of women active in the Czech Reformation. Nonetheless, some do not hesitate to surmise. For example, during his time as rector of the Bethlehem Chapel in Prague, Jan Hus "composed religious songs for the people and especially for women. Every sermon started with a Czech song, which the people sang. In this way passivity was taken from women, which up to now the Latin ceremonies had forced them and they were given the possibility to take an active part at the divine service. How much closer to God was the feeling of the simple, but more devout, Bethlehem singer!" (Císařová Kolářová 1947, p. 26). The observation is subjective opinion and is impotent of proof. Did women preach sermons, write books and pamphlets, or compose songs? If they did, one must ponder why these have been lost. Medieval women rarely wrote anything. There are three reasons for this. They normally did not have the education necessary being excluded from university study, they had few public roles where they might gain knowledge, and silence was often imposed upon them. Exceptions to this general pattern can be found amongst the religious, notably the mystics Angela of Foligno, Brigitta of Sweden, Catherine of Siena, Gertrude, Hildegard of Bingen, Julian of Norwich, and others, and a sterling exception to the rule was the twelfth-century French Héloïse. In other words, the female voice was the other voice (Bornstein 2000, p. xxii) But that other voice was never entirely silenced and throughout the history of the church, women have been heard in pulpits and in the proclamation of the Christian faith. ${ }^{63}$ The more strident or radical challenges to institutionalized religion sometimes included acts that few thinkers would endorse. Inspired by sermons in 1534, the Anabaptist Hille Feicken undertook a plot to assassinate the bishop of Münster taking the biblical Judith as example. ${ }^{64}$ Hussites were neither the first nor the last to experiment with new forms and expressions of religious life (Pinder 2020, p. 8).

Can we say there was a female voice or a female response to the Hussite initiative and the larger Czech Reformation? Or were the responses to reform essentially individual and personal without reference to gender ${ }^{65}$ Scholars continue to grapple with the challenge of developing methods wherein one might recover the female voice in order to make Hussite women visible. Of course, it is possible that this voice has been forever silenced. Further, despite the ardent protests of some feminist scholars there is no evidence to suggest that complete equality for women was ever achieved in the Hussite milieu at any time in its 
turbulent history. The introduction of the European Reformations did not alter this reality in any measurable or lasting sense. Is it possible that the problem is "less in the paucity of sources than in the inadequacy of historical methodology?" (Thomas 2007, p. 20). Future studies of Reformation, especially in largely overlooked areas like Bohemia, must take women into more fulsome account. The many fires of the Czech "Calvaries" is one place to start. Here we find linkages to the early Hussite movement and these martyrs "most closely resemble the women of Tábor" (Císařová Kolářová 1940a, p. 224).

It is worth pondering that it could be a serious blunder to subordinate the limited successes women had to the larger histories of the movement or to the more visible role of men. The result may be that these smaller, temporary, or more limited advances may eventually be forgotten with the commensurate conviction that women made little if any contributions to the larger history. ${ }^{66}$ On the other hand, there were certainly many more women in late medieval Bohemia who remained passive or had no opportunity to become public dissidents or were unable to participate in the fleeting emancipation offered to women by means of the social upheaval precipitated by the Hussite movement that resulted in a definite social revolution and a proper Reformation in religion. It is altogether too easy to generalize from a limited perspective gleaned from a superficial and hasty survey of the surviving evidence that is in any case fragmentary and too frail to support modern ambitions and agendas. That failure cannot be a factor in determining what counts as Reformation and to what extent Hussites should be assigned a significant role. "Historians have been accused of silencing past voices when they fail to find in them decidedly [contemporary] sensibilities of essentializing categories when they have instead (after long and painstaking research) discovered an unfamiliar attitude in the past. Such charges are abusive, both of the historical record and of the contemporary diversity they purport to foster" (Bynum 1995, pp. 28-29). Such historiographical sins must be avoided.

Writing at the same time the Hussite Revolution was beginning to unfold, Christine de Pisan asserted she regretted being born a woman. However, she also wrote: "I, a woman, dare ... " Written by 1405 , hers is the first book by a woman in praise of women (De Pisan 1982). Christine believed that women's incapacity was due to a lack of education not a deficiency in natural ability. But she maintained that men and women were different and ought to be treated differently. This was a medieval reflection of what most regarded as the natural order of things. It does not satisfy modern impulses. The French historian Georges Duby once pointed out that in the medieval west, women talked a great deal. Men complained that they talked too much and preachers denounced women for this fault. But for all the apparent talking, very little of what they said has survived and the female voice has been shrouded in silence (Duby 1992, p. 483) The broader tradition provides examples of women acting on their religious convictions. Klára, Marta, and Anna Marie can aid the historian in penetrating the silences and dimness of the past and these portraits and voices illuminate the contours of Reformation. There were others. In 1512, at a particularly dangerous moment in the Czech lands when the full force of the St. James Day Mandate was in play, the noblewoman Johanka Krajek (c.1455-c.1530), who lived in the town of Mladá Boleslav, declared allegiance to the Unity of Brethren faith and in 1513 took the extraordinary step of publishing a defence of their theology (Říčan 1992, pp. 100-1). There is one further consideration. "Medieval silences were crafted, and the suggestion of the unspeakable is, above all, a powerful metaphor cast in words themselves and meant to have an impact on words yet unspoken. In that sense, silences can be made legible and deciphered" (Puff 2000, pp. 41-61 at p. 51). Martyrological sources help to recover the female voice (Foxe 1563), but these texts present their own sets of challenges. ${ }^{67}$

The search for the female voice in the Hussite era is a fraught undertaking and the challenge for identifying the role of women in that history is no less complicated. Women were often excluded or marginalized for all manner of reason but even language tended to obfuscate as much as clarify. Scholars have increasingly recognized the linguistic barrier to locating the female presence. Language can also denigrate or marginalize. The medieval Latin word anus, for example, can refer either to the excretory opening at the end of the 
alimentary canal or to an "old woman" (Thomas 2015, p. 54). The association is unfortunate. The gendered nature of language in other contexts wherein only adult males are taken into account, and women and children actively excluded, creates another veil of marginalization (Hay 2001, pp. 3-10). The tendency is not medieval. It has a longer history. Alexander, bishop of Alexandria in patristic Christianity applied the term "little women" to those poor souls who had been deceived by heretics. Athanasius asserted that these little women were weak and therefore were victimized by the heretics. "The diminutive form $\gamma v v \alpha \iota k$ pı seems to be rare outside of Christian texts; the appearance of the word in Christian texts can therefore probably be attributed to the influence of 2 Timothy 3 and interpreted as an allusion to that passage" (Burrus 1991, pp. 229-48 and especially p. 238, n.29). Overall, many of the Patristic sources tend to depict heresies (and heretics) as "feminine...deceptive, irrational, foolish, weak, passive, immoral, and dangerous" (Burrus 1991, p. 239).

Jakoubek of Stříbro agreed and this facilitated his conviction that women were natural troublemakers. These stereotypes were applied to Klára, Marta and Anna Marie. But the limited sources that survive subvert that misguided opinion and it is women like these three who demonstrate the vibrancy of Hussites and Reformation and reinforce the necessity of including Hussites in the religious history of Europe. The Czech reformer Matěj of Janov summed up the case for women:

In our time women fill the houses of prayer, crowd around the pulpits, present themselves at confession with groans and abundant tears, ceaselessly recite prayers, receive with jubilation each day the sacrament of the altar, renounce entirely the vanities and the pomp of the world, abound even more each day in the charity of Christ Jesus, having a mind full of divine thoughts, spiritual consolations, prophecies and revelations. In all of this it appears that women are more than a hundred times richer than men or priests. Now the gift of prophecy and the eminent features of the Holy Spirit have been transferred to women to whom have been revealed great divine mysteries, as is manifest in the person of Hildegard the glorious virgin, of Brigitta, saint and venerable mother of a family, and on many other women dignified of God such as I have met in Paris, Rome, Nuremberg and many more still in Prague, admiring in their works the Lord Jesus. (Kybal et al. 1908-1993, lib. 1, tr. 2, reg. 4, c. 17, in vol. 1, pp. 162-63)

Evaluating the Hussite reformation by looking at women as a category for assessing that history is limited but not without merit. These episodes in the tumultuous years of the later Hussite uprising underscore issues of theology, religious practice, and female agency and force consideration of whether these should be characterized simply as aberrant and episodic or as significant indications of religious reformation. Like many women before them, these defenders of the faith were not passive recipients of religious impulses (Pinder 2020, p. 66). Instead, the lives of the women discussed in this study suggest intense engagement with theology and religious questions in the world of the European Reformations. Anna Marie Trejtlarová may not have attained the crown of martyrdom but her devotion parallels the commitment of the meek housekeeper Klára and the "manly" Marta. The witness of three obscure women in what Anna Marie called the "time of grace" and their willingness to embrace a "fiery Calvary" in Reformation Prague suggests the latter.

Funding: This research received no funding.

Conflicts of Interest: The author declares no conflict of interest.

\section{Notes}

The claim that women "were increasingly drawn to the heretics" is often stated but not demonstrated. (Grundmann 1995, p. 163; Arnold 2013) is a sound and sober assessment. (Broad and Green 2009), especially pp. 162-79 on Quakers, is useful along with (Elk 2017), pp. 27-80 who provides a stimulating elaboration around issues of literacy. (Spiritualism in Early Modern Europe 2021) contains several useful articles. (Driedger and Waite 2021) argue for moving beyond traditional paradigms and contextualize the Special Issue by encouraging more dialogue across unhelpful traditional boundaries (162). The authors stress the underlying early modern concern about ordinary people asserting personal opinions on theology. 
Merlo (1991), pp. 93-112 has shown that Waldensian women were never equal to men even in the early days. (Abels and Harrison 1979), pp. 215-51 have demonstrated that the numbers of women involved in the Cathar movement and their roles therein have been much exaggerated, while (McSheffrey 1995) argues that Lollardy appealed much more to men than women.

3 Younger female scholars in the Czech academy find the current gender approach in medieval studies rather decadent even though they acknowledge that the founders of feminist historiography deserve respect. Czech insularity and general resistance to western scholarship and its perceived feminist agenda have also served to stagnate the field. The pioneering monograph of Anna Kolářová-Císařová (noted below) now more than a century old, is almost completely unknown to the non-Czech reading scholarly community but her work reflects her diligent collection of available materials. It is possible to build on her research and use her source collection for new, attractive, and unorthodox interpretations that could stimulate interest. Those familiar with her work recognize the merit of paying tribute to her achievements as a true predecessor of modern gender studies but hitherto this has not occurred.

4 (Bainton 1971-1977) and see (Hillerbrand 2007), pp. 383-98, (Bayer 2008), pp. 15-28 and (MacCulloch 2004) for examples of that approach.

(Becker-Cantarino 1987), (Marshall 1989), (Poska et al. 2013), (Stjerna 2009), (Wiesner-Hanks 2019) and (Capern 2019). (Braddick and Walter 2001), pp. 1-42 underscores factors such as gender, age, class, social status and other considerations.

7 The most recent study is (Halama 2018), pp. 181-208 which corrects and expands our knowledge in important ways. Halama makes the essential distinction between mother and daughter that has often been confused in the historiography. He magnanimously avoids embarking on an "ungrateful critique of older works" in an effort to "correct the lapses of previous research" $p$. 182. His work is fundamental.

8 These were leading clerics amongst the Brethren. There are scattered references in (Říčan 1992), pp. 279, 333-35, 339, 342, 350, $352,355$.

9 (Profeld 1928, p. 100). The Bethlehem postil she prepared bears the inscription: “The Sunday sermons of the high-born virgin Anna Marie Treitlarová of Krošvice, who, being then eighteen years old, wrote this book with her own hand as she could remember everything from listening to the word of God from honourable men and the servants of God in the church of the Lord in Bethlehem, (to which a prayer composed by her is added at the end). Whoever might read this and discover something doubtful, should attribute this to her misunderstanding and young age and not to the servants of God, because all of us are imperfect."

10 (Profeld 1928, p. 100) and (Halama 2018, p. 185). A “kopa” was sixty Meissen Groschen.

11 (Jiřincová 2015, pp. 2-11) but mentioned much earlier in (Nováková 1891, pp. 296, 301). Both confuse Anna Marie with her mother Anna.

Text of the prayer is preserved in (Prague n.d.). Printed in (Profeld 1928, pp. 101-103) and translated from that source. I am grateful to Zdeněk David for his expert contribution to the translation. Text also in (Halama 2018, pp. 201-4).

This can be found in (Hradec n.d., p. 428) and quoted in (Profeld 1928, pp. 100-1).

This paragraph is based on the Czech funeral texts published in (Halama 2018, pp. 204-7).

(Menšík 1948, pp. 80-81), translation in (Thomas 2007, pp. 46-7).

(Spierling 2012, pp. 178-96) provides a useful survey of the ways in which reformers regarded women as leaders and authorities in religious matters.

(Brown 2007) makes useful observations on the ways in which women challenged institutional religious practice.

The idea of female agency cannot be ignored. See (Nelson 2013) and (Basch 2021), pp. 223-53. The latter suggests that wives were agents of Reformation and the idea might apply to women in general.

A searing critique of women among the Hussites appears in Jakoubek of Střibro's commentary on the Apocalypse written between 1420 and 1422. (Šimek 1932-1933, vol. 1, pp. 128-9, 571; vol. 2, pp. 25-26, 182, 257). Jakoubek was an influential voice and, as delineated below, his views carried considerable weight. In western languages see (De Vooght 1972; Soukup 2011). The Czech text appears in (Havránek et al. 1963, vol. 1, pp. 279-80). The challenges these women presented have been reviewed in (Makowski 2005).

A comment made in the "Hussite Chronicle" by Laurence of Březová. Text in (Goll 1893, p. 498). English version in (Fudge 2020, p. 220).

(Capes 1916, p. 364, no. 30; cf. p. 279) where we find the declaration: "quod eciam mulier extra peccatum existens potest conficere corpus Christi ita bene sicut sacerdos." See also (Jurkowski 2012, pp. 285-302). Text in (Fudge 2002, pp. 17-20 at p. 20).

On female preachers before the sixteenth century, see (Kienzle 1998, pp. 99-113).

Text in (Fudge 2002, p. 177).

(Šmahel 2002, vol. 2, pp. 39-40). For Anna Mochova see (Císařová Kolářová 1940b, pp. 159-63).

Partial translation of her important letter is in (Klassen 1999, p. 219). 
(Davis 1975, p. 94); (Conrad and Gritschke 1999) points out that in German-Protestant territories women did find opportunities for public and leadership roles. Charlotte Methuen, (Methuen 2013, pp. 82-109) examines the ways in which women were able to contribute publicly to religious discourse.

On Kalenec, see (Brock 1957, pp. 244-52) and (Zeman 1969, pp. 64-69). Amos had worked as a wax dealer in Uherský Brod but later moved to Vodňany where he gained a certain prominence among the Brethren.

"This Klara was the widow of a Prague townsman living in the street and house called Na Sbirohu in the New Town near [the church of] St. Katherine. She was in her sixties. An old man, Mikulas, lived there as well. He worked with a lathe producing spindles." (Písař 1907, p. 217). As for the location of the street and house Na Sbirohu, there is no reason to doubt Šimák's view given his expertise on the topography of old Prague.

(Brock 1957, p. 245, n.13) claims Mikuláš was a bishop. This seems unlikely given disclosures he made during formal interrogations wherein he revealed his limited clerical functions. Comments by its modern editor (Písař 1907, vol. 6, pp. v-xxxii, especially pp. v-xx). For additional comment see (Písař 1907, pp. xxx-xxxii and Písař 1907, pp. 353-54).

"They both looked up their pastor, as it is already written-who sold them to the Praguers, obtaining for them one silver piece of the [thirty?] silver pieces, for which Judas had sold his master, and then again returned them to the Pharisees and Sadducees, and they [Klára and Mikuláš] were put in jail." (Písař 1907, p. 217). The interrogatories and responses are in (Písař 1907, pp. 209-11).

According to Thomas: "Since so long as the proper subject remains its proper passions must also remain, and when it is corrupted they also must be corrupted, it follows that these powers which use no bodily organ for their actions must needs remain in the separated body, while those which use a bodily organ must needs be corrupted when the body is corrupted: and such are all the powers belonging to the sensitive and the vegetative soul." Summa Theologiae IIIa Q.70 a.1 suppl. (Aquinas 1911, p. 2826). Of course, this leads on to an even more pertinent issue, especially relevant in a heresy trial. If there is no body, how can the fires of hell burn? Thomas provides the answer in a.3 by suggesting that the soul of the damned is incorporated into the body of the fire, and by that means experiences agonies through the intellectual realization of that union. I am grateful to Stephen Lahey for advice. Specifically, “zvláštní apoštol” in (Písař 1907, p. 210).

The text appears in (Palacký 1840-1872, vol. 5, pp. 418-27).

On the schism, see (Brock 1957, pp. 153-82).

Brother Matěj of Kunvald was the first bishop of the Unity (c.1442-1500). (Říčan 1992, pp. 61-68, 71-74).

The story is detailed in (Puff 1997, pp. 165-95).

(Goodich 1979, p. 31). The treatise of Peter Damian is the only medieval text that deals specifically with sodomy and the focus of the polemic is on those in holy orders. A complete translation is available in (Blum 1992, pp. 3-53).

At the forefront of provocative and stimulating studies is (Jordan 1997) which constitutes an innovative examination of medieval sources. The import of the argument mounted by Peter Damian and summarised in (Jordan 1997, p. 66).

"Adolescence ... could begin at the age of 9 but also at 14; you could span the years between 14, or 18, and up to 25, 28, or simply until marriage." (Krausman Ben-Amos 1994, p. 11).

For a broader consideration, see (Elliott 2020).

Specifically, "falešným prorokóm" in (Písař 1907, p. 211).

The (Šimák 1907, p. 340) incorrectly believes Martin to be the mayor.

Little is known of Hynek, but his brother Václav of Pergnov received urban rights in Prague in 1521 and in 1522 bought a house in Pořičíi. (Písař 1907, p. 213). (Písař 1907, p. 212) noting manuscript variants.

The exchange appears to have been protracted. See (Písař 1907, pp. 212-14) and in more abbreviated form in (Šimák 1907, vol. 6, p. 340).

(Šimák 1907, vol. 6, p. 340). The writer erroneously identifies the mayor as Jiř́k Komedka. On the earlier period see (Cook 1982, pp. 329-42; Bartlová 2009, pp. 115-26; Sedláčková 2007, pp. 77-85), and (Bělohlávková 1992, pp. 53-64). In the sixteenth century, Andreas Karlstadt, “On the Removal of Images," in (Karlstadt 1995, pp. 100-28).

(Písař 1907, p. 216) noting the testimony of other manuscripts.

56 This is an error because Klára had no daughters. This may refer to Salomé, the daughter of Černý of Hlubočerp, noted in the last will and testament of Klára, 18 December 1526. (Písař 1907, p. 216) and (Šimák 1907, p. 341). On the matter of Klára's daughter, see (Šimák 1903, pp. 355-56). 
The late medieval Pořičí stream is known today as Na Poříćí Street in Prague.

The most recent important contribution on Askew is (Wabuda 2021).

Rebaptism, like denial of Trinitarian doctrine, could attract severe punishments. These included suppression, banishment and penalties under heresy laws. Capital punishment is not specifically noted. (Mommsen et al. 1886, vol. 1, at 2.2., 4.1-8, 5.2 and 7.6). Pertinent accounts in (Písař 1907, pp. 218-19) and (Borovy 1868, p. 32), and (Císařová Kolářová 1942, pp. 252-55). (Kienzle 1998) provides an introduction to that overlooked and underappreciated history. (Kobelt-Groch 1993) suggest the more radical forms of Reformation afforded women greater scope for participation. These opportunities ranged from support roles to the actions proposed by Hille Feiken (pp. 64-132). (Wiesner-Hanks 2020) adroitly shows how Christianity has shaped constructs of gender. With respect to a similar observation about women in the radical reforms in the sixteenth-century see (Kobelt-Groch 1993, p. 30). John Foxe's Acts and Monuments at: https://www.dhi.ac.uk/foxe/ (accessed on 15 April 2021) (Zieglschmid 1943) and (Van Braght 1950) are among the more famous.

\section{References}

Abels, Richard, and Ellen Harrison. 1979. The Participation of Women in Languedocian Catharism. Medieval Studies 41: $215-51$. [CrossRef]

Aquinas, Thomas. 1911. The Summa Theologiae of St. Thomas Aquinas. Translated by the Fathers of the English Dominican Province. New York: Benzinger Brothers.

Arnold, John. 2013. Gender and Heresy. In The Oxford Handbook of Medieval Women and Gender. Edited by Judith M. Bennett and Ruth Mazo Karras. New York: Oxford University Press, pp. 496-509.

Bainton, Roland H. 1971-1977. Women of the Reformation. 3 vols, Minneapolis: Augsburg.

Bartlová, Milena. 2009. Understanding Hussite Iconoclasm. Bohemian Reformation and Religious Practice 7: 115-26.

Basch, Rachel. 2021. Agents of the Reformation: Margaret Cranmer, Anne Hooper and Elizabeth Coverdale. In The Power of the Individual in English Reformation History. Edited by David J. Crankshaw and George W. C. Gross. New York: Palgrave Macmillan, pp. 223-53.

Bayer, Oswald. 2008. Martin Luther's Theology: A Contemporary Interpretation. Translated by T. H. Trapp. Grand Rapids: Eerdmans.

Becker-Cantarino, Barbara. 1987. Der lange Weg zur Mündigkeit: Frau und Literatur, 1500-1800. Stuttgart: Metzler.

Beilin, Elaine V., ed. 1996. The Examinations of Anne Askew. New York: Oxford University Press.

Bělohlávková, Jan. 1992. Die Ansichten über Bilder in Werke der tschechischen Reformprediger. Studie o rukopisech 29: 53-64.

Benedict, Philip. 2002. Christ's Churches Purely Reformed: A Social History of Calvinism. New Haven: Yale University Press.

Owen J. Blum, trans. 1992, Peter Damian Letters 31-60. Washington, DC: The Catholic University of America Press.

Translated and Edited by Daniel Bornstein. 2000, Life and Death in a Venetian Convent: The Chronology and Necrology of Corpus Domini, 1395-1436. Chicago: University of Chicago Press.

Borovy, Klement, ed. 1868. Jednání a dopisy Konsistoře katolické i utrakvistické. Prague: I.L. Kober, vol. 1.

Braddick, Michael J., and John Walter, eds. 2001. Negotiating Power in Early Modern Society: Order, Hierarchy and Subordination in Britain and Ireland. Cambridge: Cambridge University Press.

Broad, Jacqueline, and Karen Green. 2009. A History of Women's Political Thought in Europe, 1400-1700. New York: Cambridge University Press.

Brock, Peter. 1957. The Political and Social Doctrines of the Unity of Czech Brethren in the Fifteenth and Early Sixteenth Centuries. The Hague: Mouton.

Brodský, Pavel. 2009. The History of the Preservation and Restoration of the Jena Codex. In The Jena Codex. 2 vols. Translated by Barbara Day. Prague: Gallery, pp. 43-56.

Brown, Sylvia, ed. 2007. Women, Gender, and Radical Religion in Early Modern Europe. Leiden: Brill.

Burrus, Virginia. 1991. The Heretical Woman as Symbol in Alexander, Athanasius, Epiphanius, and Jerome. Harvard Theological Review 84: 229-48. [CrossRef]

Bynum, Caroline. 1995. Why all the Fuss about the Body? A Medievalist's Perspective. Critical Inquiry 22: 1-33. [CrossRef]

Capern, Amanda L., ed. 2019. The Routledge History of Women in Early Modern Europe. New York: Routledge.

Capes, William Wolfe, ed. 1916. Registrum Johannis Trefnant Episcopi Herefordensis. Canterbury and York Series; London: Canterbury and York Society, vol. 20.

Císařová Kolářová, Anna. 1940a. Dvě starobratrské mučednice Klára a Marta. In Královny, Kněžny a Velké Ženy České. Edited by Karel Stloukal. Prague: Vilímek, pp. 221-24.

Císařová Kolářová, Anna. 1940b. Typy žen husitských a paní Anna z Mochová. In Královny, Kněžny a velké Ženy České. Edited by Karel Stloukal. Prague: Vilímek, pp. 159-63.

Císařová Kolářová, Anna. 1942. Žena v Jednotě bratrské: Zásady, postavy a dědictví. Prague: Kalich.

Císařová Kolářová, Anna. 1947. Posluchačky v kapli betlémské. Prague: Kalich.

Comenius, John Amos. 1648. Historia Persecutionum Ecclesiae Bohemicae, unpublished work. 
Conrad, Anne, and Caroline Gritschke, eds. 1999. In Christo ist weder Man noch Weyb: Frauen in der Zeit der Reformation und der Katholischen Reform. Münster: Aschendorff.

Cook, William R. 1982. The Question of Images and the Hussite Movement in Prague. Cristianesimo Nella Storia 3: $329-42$.

Corbellini, Sabrina, and Sita Steckel. 2019. The Religious Field during the Long Fifteenth Century: Framing Religious Change beyond Traditional Paradigms. Church History and Religious Culture 99: 303-29. [CrossRef]

David, Zdeněk V. 2003. Finding the Middle Way: The Utraquists' Liberal Challenge to Rome and Luther. Washington, DC: Woodrow Wilson Center Press, Baltimore: Johns Hopkins University Press.

Davis, Natalie Zemon. 1975. Society and Culture in Early Modern France. Stanford: Stanford University Press.

De Pisan, Christine. 1982. The Book of the City of Ladies. Translated by Earl Jeffrey Richards. New York: Persea Books.

De Vooght, Paul. 1972. Jacobellus de Stř́bro (+1429), premier Théologien du Hussitisme. Louvain: Publications universitaires de Louvain.

Demetz, Peter. 1997. Prague in Black and Gold: Scenes from the Life of a European City. New York: Hill and Wang.

Dolany, Štěpán. 1721-1729. Epistolae ad Hussitas. In Thesaurus Anecdotorum Novissimus seu Veterum Monumentorum. Edited by Bernard Pez. 6 vols. Augsburg: Philippi, Martini, \& Joannis Veith Fratrum, vol. 4, pp. 503-706.

Douglass, Jane Dempsey. 1985. Women, Freedom and Calvin. Philadelphia: Westminster Press.

Driedger, Michael, and Gary K. Waite. 2021. From 'the Radical Reformation' to 'the Radical Enlightenment'?: The Specter and Complexities of Spiritualism in Early Modern England, Germany, and the Low Countries. Church History and Religious Culture 101: 135-66. [CrossRef]

Duby, George. 1992. Affidavits and Confessions. In A History of Women in the West, vol. 2 Silences of the Middle Ages. Edited by Christiane Klapisch-Zuber. Cambridge: The Belknap Press of Harvard University Press, pp. 483-91.

Elk, Martine van. 2017. Early Modern Women's Writing: Domesticity, Privacy, and the Public Sphere in England and the Dutch Republic. New York: Palgrave Macmillan.

Elliott, Dyan. 2020. The Corrupter of Boys: Sodomy, Scandal, and the Medieval Clergy. Philadelphia: University of Pennsylvania Press.

Foxe, John. 1563. Acts and Monuments. Available online: https://www.dhi.ac.uk/foxe/ (accessed on 15 April 2021).

Fudge, Thomas A. 1996. The Problem of Religious Liberty in Early Modern Bohemia. Communio Viatorum 38: 64-87.

Fudge, Thomas A. 2002. The Crusade against Heretics in Bohemia, 1418-1437: Sources and Documents for the Hussite Crusades. Aldershot: Ashgate.

Fudge, Thomas A. 2010. Jan Hus: Religious Reform and Social Revolution in Bohemia. London: I.B. Tauris.

Fudgé, Thomas A. 2016. Medieval Religion and its Anxieties: History and Mystery in the Other Middle Ages. New York: Palgrave Macmillan.

Fudge, Thomas A. 2020. Origins of the Hussite Uprising: The Chronicle of Laurence of Březová (1414-1421). London: Routledge.

Goll, Jaroslav, ed. 1893. Fontes Rerum Bohemicarum. Prague: Nákladem nadání Františka Palackého, vol. 5.

Goodich, Michael. 1979. The Unmentionable Vice: Homosexuality in the Later Medieval Period. Santa Barbara: ABC-Clio.

Gregory, Brad S. 1999. Salvation at Stake: Christian Martyrdom in Early Modern Europe. Cambridge: Harvard University Press.

Grundmann, Herbert. 1995. Religious Movements in the Middle Ages: The Historical Links between Heresy, the Mendicant Orders, and the Women's Religious Movement in the Twelfth and Thirteenth Century, with the Historical Foundations of German Mysticism. Translated by Steven Rowan. Notre Dame: University of Notre Dame Press.

Halama, Ota. 2018. Anna Marie Trejtlarová z Krošvic (†9. ledna 1626). Pražský Sborník Historický 46: 181-208.

Halle. 1584. Franckesche Stiftungen MS AFSt/H P 9. Unpublished work.

Hanušová, Barbora. 2013. Ženy v reformaci. Unpublished thesis, Charles University, Prague, Czech Republic.

Havránek, Bohuslav, Josef Hrabák, and Jiří Daňhelka, eds. 1963. Výbor z české literatury doby husitské. 2 vols. Prague: Českoslovenká akademie věd.

Hay, David. 2001. Gender Bias and Religious Intolerance in Accounts of the Massacres of the First Crusade. In Tolerance and Intolerance: Social Conflict in the Age of the Crusades. Edited by Michael Gervers and James M. Powell. Syracuse: Syracuse University Press, pp. 3-10.

Heymann, Frederick G. 1968. The Impact of Martin Luther upon Bohemia. Central European History 1: 107-130. [CrossRef]

Hillerbrand, Hans J. 2007. The Division of Christendom. Louisville: Westminster John Knox Press.

Hradec, Králové. n.d. Museum of Eastern Bohemia, MS 62. Unpublished Work.

Hrejsa, Ferdinand. 1947-1950. Dějiny křest'anství v Československu. 6 vols. Prague: Vydavatel Husova československá evangelická fakulta bohoslovecká.

Hus, Jan. 1975. Výklad desatera [Commentary on the Ten Commandments]. In Magistri Iohannis Hus Opera Omnia. Edited by Amedeo Molnár. Prague: Academia, vol. 1, pp. 113-329.

Jena Codex. 1490-1510. Prague, National Museum Library MS IV B 24. Unpublished work.

Jiřincová, Barbora. 2015. Příběh jedné pobělohorské emigrantky do Saska. Anna Marie Treitlarová z Krošvic. Fontes Nissae-Prameny Nisy 16: 2-11.

Joldersma, Hermina, and Louis Grijp, eds. 2001. Elisabeth's Manly Courage: Testimonials and Songs of Martyred Anabaptist Women in the Low Countries. Milwaukee: Marquette University Press.

Jordan, Mark D. 1997. The Invention of Sodomy in Christian Theology. Chicago: The University of Chicago Press.

Jurkowski, Maureen. 2012. Who was Walter Brut? English Historical Review 127: 285-302. [CrossRef]

Kaminsky, Howard. 1967. A History of the Hussite Revolution. Berkeley: University of California Press. 
Karant-Nunn, Susan C., and Merry E. Wiesner-Hanks, eds. 2003. Luther on Women: A Sourcebook. Cambridge: Cambridge University Press.

Karlstadt, Andreas. 1995. On the Removal of Images. In The Essential Carlstadt. Translated and Edited by E.J. Furcha. Scottdale: Herald Press, pp. 100-28.

Kienzle, Beverly Mayne. 1998. The Prostitute-Preacher: Patterns of Polemic against Medieval Waldensian Women Preachers. In Women Preachers and Prophets through Two Millennia of Christianity. Edited by Beverly Mayne Kienzle and Pamela J. Walker. Berkeley: University of California Press, pp. 99-113.

Klassen, John M. 1999. Warring Maidens, Captive Wives, and Hussite Queens: Women and Men at War and at Peace in Fifteenth Century Bohemia. New York: Columbia University Press.

Kobelt-Groch, Marion. 1993. Aufsässige Töchter Gottes: Frauen im Bauernkrieg und in den Täuferbewegungen. Frankfurt: Campus.

Kolářová-Císařová, Anna. 1915. Žena v hnutí husitském. Prague: Sokolice.

Krausman Ben-Amos, Ilana. 1994. Adolescence and Youth in Early Modern England. New Haven: Yale University Press.

Kybal, Vlastimil, Otakar Odložilík, and Jana Nechutová, eds. 1908-1993. Matěj of Janov. In Regulae veteris et novi testamenti. 6 vols. Prague, Innsbruck and Munich: Universitního Knihkupectví Wagnerova and Oldenbourg.

MacCulloch, Diarmaid. 2004. Reformation: Europe's House Divided 1490-1700. London: Allen Lane.

Madigan, Kevin, and Carolyn Osiek, eds. 2005. Ordained Women in the Early Church: A Documentary History. Baltimore: The Johns Hopkins University Press.

Makowski, Elizabeth. 2005. A Pernicious Sort of Woman: Quasi-Religious Women and Canon Lawyers in the Later Middle Ages. Washington, DC: The Catholic University of America Press.

Marshall, Sherrin, ed. 1989. Women in Reformation and Counter-Reformation Europe: Public and Private Worlds. Bloomington: Indiana University Press.

Matheson, Peter. 1995. Argula von Grumbach: A Woman's Voice in the Reformation. Edinburgh: T\&T Clark.

McSheffrey, Shannon. 1995. Gender and Heresy: Women and Men in Lollard Communities, 1420-1530. Philadelphia: University of Pennsylvania Press.

Menšík, Jan, ed. 1948. Počátky Staročeské Mystiky. Prague: Matice česká.

Merlo, Grado G. 1991. Sulle misere donnicciuole che predicavano. In Valdesi e Valdismi Medievali, vol. II: Identità valdesi nella Storia e Storiografia: Studi e Discussion. Turin: Claudiana, pp. 93-112.

Methuen, Charlotte. 2013. And Your Daughters Shall Prophesy! Luther, Reforming Women and the Construction of Authority. Archiv für Reformationsgeschichte 104: 82-109. [CrossRef]

Meyer, Johannes. 2019. Women's History in the Age of Reformation: Johannes Meyer's Chronicle of the Dominican Observance. Translated by Claire Taylor Jones. Toronto: Pontifical Institute of Medieval Studies.

Molnár, Amedeo, ed. 1985. Jan Hus, On Simony. In Magistri Iohannis Hus Opera Omnia. Prague: Academia, vol. 4, pp. $187-270$.

Mommsen, Theodor, Rudolf Schoell, Paul Krueger, and Wilhelm Kroll, eds. 1886. Corpus juris civilis, Editio Stereotype Altera: Institutiones, Digesta, Codex Justinianus, Novellae E Opus Schoelli Morte Interceptum. Berlin: Weidmann, vol. 1.

Nelson, Karen, ed. 2013. Attending to Early Modern Women: Conflict and Concord. Newark: University of Delaware Press.

Nováková, Teréza. 1891. Slavín žen českých: Od nejstarších dob do znovuzrození národa českého. Prague: Libuše, vol. 1.

Palacký, František, ed. 1840-1872. Archiv český. 6 vols. Prague: Stawy Králowstwj Českého.

Palacký, František, ed. 1869. Documenta Mag. Joannis Hus Vitam, Doctrinam, Causam in Constantiensi Concilio Actam et Controversias de Religione in Bohemia annis 1403-1418 motas illustrantia. Prague: Tempsky.

Pelhřimov, Mikuláš. 1430. Latin postil on the Apocalypse, Vienna, Österreichische Nationalbiblothek, MS 4520. Unpublished work.

Pinder, Janice. 2020. The Abbaye du Saint Esprit: Spiritual Instruction for Laywomen, 1250-1500. Turnhout: Brepols.

Písař, Bartoš. 1907. Pražská kronika od léta Páně 1524 do konce léta 1530. In Fontes Rerum Bohemicarum. Edited by Josef V. Šimák. Prague: Nákladem nádání Františka Palackého, vol. 6, pp. 1-296.

Poska, Allyson M., Jane Couchman, and Katherine A. McIver, eds. 2013. The Ashgate Research Companion to Women and Gender in Early Modern Europe. Farnham: Ashgate.

Prague. n.d. Library of the Evangelical Theological Faculty of Charles University, MS IK 2604, fols. 102r-107v. Unpublished work.

Příbram, Jan. 2000. Život kněži táborských. Edited by Jaroslav Boubín. Příbram: Státní okresní Příbram a Okresní museum Příbram.

Profeld, Bedřich. 1928. Modlitba Marie Anny Treitlarové z Krošvic. Reformačni Sbornik 2: 100-3.

Puff, Helmut. 1997. Localizing Sodomy: The Priest and Sodomite in Pre-Reformation Germany and Switzerland. Journal of the History of Sexuality 8: 165-95.

Puff, Helmut. 2000. Female Sodomy: The Trial of Katherina Hetzeldorfer (1477). Journal of Medieval and Early Modern Studies 30: 41-61. [CrossRef]

Puff, Helmut. 2003. Sodomy in Reformation Germany and Switzerland 1400-1600. Chicago: University of Chicago Press.

Říčan, Rudolf. 1992. The History of the Unity of Brethren. Translated by C. Daniel Crews. Winston-Salem: The Moravian Church in America.

Schäufele, Wolfgang. 1966. Das Missionarische Bewusstsein und Wirken der Täufer, Dargestellt nach oberdeutschen Quellen. NeukirchenVluyn: Neukirchener Verlag.

Sedláčková, Kristína. 2007. Jakoubek of Stříbro and the So-Called Sermon in Týn Church of 31 January 1417. Bohemian Reformation and Religious Practice 6: 77-85. 
Šimák, J. V. 1903. Kronika Bartoše písaře. Věstnik České Akademie Císare Františka Josefa pro Vědy, Slovesnost a Umění 12: 645-671.

Šimák, Josef V., ed. 1907. Paměti o bouři Pražské roku 1524. In Fontes Rerum Bohemicarum. Prague: Nákladem nádání Františka Palackého, vol. 6, pp. 299-342.

Šimek, František, ed. 1932-1933. Jakoubek ze Stříbra Výklad na Zjevení sv. Jana. 2 vols. Prague: Nákladem Komise vydávání pramenů českého hnutí náboženského.

Šmahel, František. 1993. Husitská Revoluce. 4 vols. Prague: Historický ústav.

Šmahel, František. 2002. Die Hussitische Revolution. 3 vols. Translated by Thomas Krzenck. Hannover: Hahnsche Buchhandlung.

Snyder, C. Arnold, and Linda A. Huebert Hecht, eds. 1996. Profiles of Anabaptist Women: Sixteenth-Century Reforming Pioneers. Waterloo: Wilfrid Laurier University Press.

Soukup, Pavel. 2011. Reformní kazatelsvtí a Jakoubek ze Střibra. Prague: Filosofia.

Spierling, Karen E. 2012. Reformation Understandings of Women, Marriage, and Family. In The T E T Clark Companion to Reformation Theology. Edited by David M. Whitford. London: T \& T Clark, pp. 178-96.

Spiritualism in Early Modern Europe. 2021. A special issue of Church History and Religious Culture 101 (Nos. 2-3, 2021). Unpublished work.

Stjerna, Kirsi. 2009. Women and the Reformation. Oxford: Blackwell.

Sylvius, Aeneas. 1571. Libros Antonii Panormitae poetae, de dictis et factis Alphonsi regis memoribilibus, commentaries, Book II. In Aeneae Sylvii Piccolominei Opera. Basel: Henricpetrina.

Tadra, Ferdinand, ed. 1893. Soudní Akta Konsistoře Pražské = (Acta judicaria Consistorii Pragensis). Prague: Česká akademie císaře Františka Josefa pro vědy, slovesnost a uměni, vol. 1, pp. 1373-79.

Tentler, Thomas N. 1977. Sin and Confession on the Eve of the Reformation. Princeton: Princeton University Press.

Thomas, Alfred. 2007. A Blessed Shore: England and Bohemia from Chaucer to Shakespeare. Ithaca: Cornell University Press.

Thomas, Alfred. 2015. Reading Women in Late Medieval Europe: Anne of Bohemia and Chaucer's Female Audience. New York: Palgrave Macmillan.

Thompson, John Lee. 1992. John Calvin and the Daughters of Eve. Geneva: Libraire Droz.

Torjesen, Karen Jo. 1993. When Women were Priests: Women's Leadership in the Early Church and the Scandal of Their Subordination in the Rise of Christianity. San Francisco: Harper.

Van Braght, Thieleman J., ed. 1950. The Bloody Theater or Martyrs Mirror. Scottdale: Herald Press.

Ververková, Kamila. 2021. The Four Articles of Prague within the Public Sphere of Hussite Bohemia. Translated by Angelo Shaun Franklin. Lanham: Lexington Books.

Wabuda, Susan. 2021. The Power of the Individual in English Reformation History. Edited by David J. Crankshaw and George W.C. Gross. New York: Palgrave Macmillan, pp. 255-90.

Wiesner-Hanks, Merry. 2019. Women and Gender in Early Modern Europe, 4th ed. Cambridge: Cambridge University Press.

Wiesner-Hanks, Merry. 2020. Christianity and Sexuality in the Early Modern World: Regulating Desire, Reforming Practice, 3rd ed. New York: Routledge.

Worms, Burchard. 1880. Decretorum libri viginti. In Patrologiae Cursus Completus, Series Latina. Edited by Jacques Paul Migne. Paris: Garnier, vol. 140, pp. 498-1058.

Zeman, Jarold Knox. 1969. The Anabaptists and the Czech Brethren in Moravia 1526-1628: A Study of Origins and Contacts. The Hague: Mouton.

Zieglschmid, A. J. F., ed. 1943. Die älteste Chronik der Hutterischen Brüder. Ithaca: The Cayuga Press. 